

\section{DISCLAIMER}

This report was prepared as an account of work sponsored by an agency of the United States Government. Neither the United States Government nor any agency Thereof, nor any of their employees, makes any warranty, express or implied, or assumes any legal liability or responsibility for the accuracy, completeness, or usefulness of any information, apparatus, product, or process disclosed, or represents that its use would not infringe privately owned rights. Reference herein to any specific commercial product, process, or service by trade name, trademark, manufacturer, or otherwise does not necessarily constitute or imply its endorsement, recommendation, or favoring by the United States Government or any agency thereof. The views and opinions of authors expressed herein do not necessarily state or reflect those of the United States Government or any agency thereof. 


\section{DISCLAIMER}

Portions of this document may be illegible in electronic image products. Images are produced from the best available original document. 
IS -757

Engineering and Equipment (UC-38) TID 4500, June 1, 1964

\section{UNITED STATES ATOMIC ENERGY COMMISSION.}

Research and Development Report

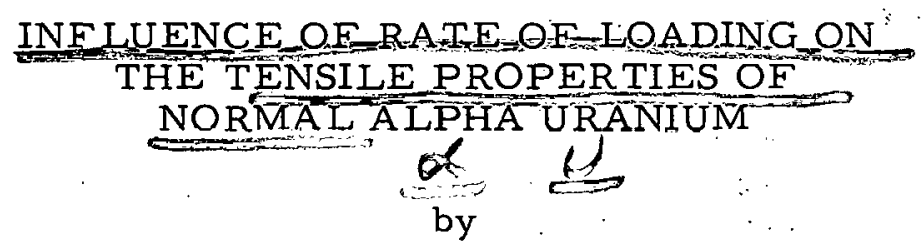

Philip Arthur Loretan and Glenn Murphy

August, 1963

\section{Ames Laboratory}

at

Iowa State University of Science and Technology F. H. Spedding, Director

Contract W-7405 eng-82 
IS -652

This report is distributed according to the category Engineering and Equipment (UC-38) as listed in TID 4500, June 1, 1964.

\section{$\underline{\text { Legal Notice }}$}

This report was prepared as an account of Government sponsored work. Neither the United States, nor the Commission, nor any person acting on behalf of the Commission:

A. Makes any warranty of representation, express or implied, with respect to the accuracy, completeness, or usefulness of the information contained in this report, or that the use of any information; apparatus, method, or process disclosed in this report may not infringe privately owned rights; or

B. Assumes any liabilities with respect to the use of, or for damages resulting from the use of any information, apparatus, method, or process disclosed in this report.

As used in the above, "person acting on behalf of the Commission" includes any employee or contractor of the Commission, or employee of such contractor, to the extent that such employee or contractor of the Commission, or employee of such contractor prepares, disseminates, or provides access to, any information pursuant to his employment of contract with the Commission, or his employment with such contractor.

Printed in U.S.A. Price \$ $\begin{array}{r}3.00 \\ 1.75\end{array}$. Available from the

Office of Technical Services

U. S. Department of Commerce

Washington 25, D. C. 
TABLE OF CONTENTS

Page

INTRODUCTION. .......................

REVIEW OF LITERATURE................ 3

OBJECTIVES OF THE INVESTIGATION............. 9

MATERIAL AND APPARATUS ............... 10

EXPERIMENTAL PROCEDURE AND RESULTS $\ldots \ldots \ldots \ldots \ldots$

DISCUSSION OF RESULTS. . . . . . . . . . . . . . 45

SUMMARY AND CONCLUSIONS ................. 54

SUGGESTED TOPICS FOR FURTHER INVESTIGATION . . . . $\quad 56$

LITERATURE CITED ................. 57

APPENDIX ......................... 60 
IS - 757 


\title{
INFLUENCE OF RATE OF LOADING ON
}

THE TENSILE PROPERTIES OF

NORMAL ALPHA URANIUM*

Philip A. Loretan and Glenn Murphy

\begin{abstract}
Forty tensile tests were carried out on normal alpha uranium in order to determine the influence of the rate of loading and temperature on its tensile properties. These tests were conducted at eleven different temperatures in the temperature range from 25 to $600^{\circ} \mathrm{C}$ for three constant loading rates $\left(0.0017 \mathrm{~min}^{-1}, 0.0130 \mathrm{~min}^{-1}\right.$, and 0.0400 $\min ^{-1}$ ). The properties considered were tensile strength, per cent elongation (in 1.5 in. gage length), percentage reduction in area, yield strength, and modulus of elasticity. All of these properties were more strongly affected by a change in temperature than they were by a change in rate of loading. Graphs showing data for each of the five properties $v s$ temperature and also as a function of rate of loading are displayed to indicate specific effects. Original stress-strain curves included along with graphs indicating the slopes of each of these curves (subsequent to the initial elastic strain portion) as a function of temperature and rate of loading.
\end{abstract}

*This report is based on an M. S. thesis submitted by Philip A. Loretan to Iowa State University, Ames, Iowa, August, 1963. 


\section{INTRODLCTION}

A number of experimental analyses have been conducted on uranium because of the usefulness of the material. Several investigators have even gathered extensive data in order to establish the tensile properties of uranium. However, as far as can be found in the literature, no one has ever tried to observe the influence that the rate of loading has on the tensile or mechanical properties of uranium.

The author became interested in the subject as a result of work he had carried out on the flexural creep properties of uranium. Initially, he wondered whether or not the shorttime tensile test could be used to predict the flexural creep stress in a beam. For plastic flow, the equation $\epsilon=\left.A 0^{m}\right|_{\dot{\epsilon}, T}$ relating stress $(\sigma)$ to plastic strain $(\epsilon)$, strain rate $(\dot{\epsilon})$ and temperature $(T)$ with the constant $A$, seems to hold well for urarium in a short-time tensile test. Thus, it was felt that it might be possible to utilize $\mathrm{m}$, the slope of the stress versus strain curve on $10 \mathrm{~g}$ paper, to predict the stress in a beam at any position, for any temperature. To do so, one would utilize the cerived flexural creep formula,

$$
\sigma_{y}=\left[\frac{M h}{2 I}\left(\frac{2 y}{h}\right)^{\frac{1}{m}}\left(\frac{2 m+1}{3 m}\right)\right] \text { where } m \text { is normaily the slope }
$$

taken from a tensile creep test. In this formula, $\sigma_{y}$ is the stress at the distance $y$ from the neutral axis of the beam, $M$ is the bending moment, $b$ is the $y$ distance at the outer 
edge of the beam and $I$ is the moment of inertia. If $m$ is found to be the same for a short time tensile test as it is during a tensile creep test, then using the slope from either test would be consicered valid in the aforementioned formula. Of course, a short-time tensile test is much more easily performed and this is where the advantage is apparent. However, since a low strain rate during a short-time tensile test can be classified as a creep test (1), the interest will lie in what happens when the rate is increased. If the higher rate of loading changes the slope considerably at a given temperature, one would in that case, not be permitted to interchange m's. However, if the slope does not change appreciably, then one could validly use the slope found at any rate of loading. Thus, a principal objective of this analysis was to determine the effect of the rate of loading on the slope, ie. actually on the stress-strain curve.

So a single investigation prompted the analysis considered in this thesis but the results of the effort were of a broader nature. Not only were data collected on the tensile properties of normal alpha uranium but the work performed provided insight into twin and slip mechanisms of deformation in uranium and also strain hardening in that material. 


\section{REVIEL OF LITERATURE}

Many reports on the investigations of the influence of the rate of loading on a wide variety of materials have been published. Rather than consider the publications on each material separately however, reports and articles were sought which principally considered the overall influence of the loading rate on several materials. Thus, the following reviews will be primarily oriented to such an approach.

Bernett (1) found that changes in the speed of testing, especially at higher temperatures, produced great differences in tensile and compressive strengths. His analysis of the mechanical properties of four metallic sheet materials were carried out at speeds from 0.00001 to $0.1 \mathrm{inch} / \mathrm{inch} / \mathrm{sec} .$, at various temperatures. Some of his conclusions were

1. For limited amounts of strain, the compressive and tensile behavior of these materials is similar.

2. In evaluating both tensile and compressive strengths, the speed of testing, ie. strain rate, is very important, particulariy at high test temperatures.

3. The modulus of elasticity was insensitive to strain rate in all cases except at elevated temperatures on one particular material.

4. Creep at high temperatures and high stress levels is a critical factor both in tension and compression. Results here indicate that large plastic deformations 
can occur in a time interval of the order of a fev seconds :

5. At high temperatures, creep rates can be roughly estimated from the tensile stress-strain curves, ie. at the stress level binere the stress-strain curve is essentially horizontal, the creep rate is approximately equal to the tensile testing strain rate. Moon and Campbe11 (2) have draw stress versus strain rate plots from tensile data for many netals and alloys. The tests were performed at room temperature and also at elevated temperature for the purpose of illustrating tire effects of increasing strain rates. They found the general trends of the analysis for each material were as follows:

1. At room temperature, yield and tensile strengths of the material either are not affected or are increased slightly with increasing strain rate.

2. At slightly elevated temperatures the effect is, in general, similar to that at room temperature, if the material has negligible tendency to creep at stresses lower than the yield strength and remains in a stable condition. Ilowever, the yield and tensile strengths are usua11y lower, dependent on temperature. Under these conditions, the length of tine at which the specimer is maintained at the testing temperature before it is loaded has little effect on its strength. 
3. At high temperatures, substantial increases are caused in yield and tensile strengths with increasing strain rate, if the material tends to creep at stresses lower than the yield strength. Yield and tensile strengths tend to coincide for a given material as testing temperature is increased.

4. At a given temperature, the elastic modulus of a material is relatively constant regardless of strain rate.

5. Effects of strain rate on ductility are not constant.

6. Reactions which change the structure of the material will affect its properties when it is heated to a temperature at which the reaction can proceed. The reactions considered may be precipitation hardening, strain aging, overaging, tempering, recrystallization, and grain growth, or other reactions or combinations of them.

Steidel and Makerov (3) used static strain rates of $10^{-5}$, $10^{-4}$ and $10^{-2} \mathrm{inch} / \mathrm{inch} / \mathrm{sec}$. on the engineering materials with which they worked. All the naterials showed an increase in yield strength and tensile strength with strain rate increases. Most of the materials displayed an increase in elongation at fracture with increased strain rate. The per cent reduction in area was found to be greater as strain rate increases for the majority of materials tested also. 
Davis (4) found that plots of stress and yield point elongation as functions of the rate of loading, displaying ultimate strength, yield point and yield point elongation are definitely influenced by the rate of loading. The effect is very noticeable especially at the faster rates.

He further stated that since stress is a function of both strain and strain rate, an increase in stress may be caused by an increase in either the strain or the strain rate. Thus, the rate of strain hardening nust be expressed by the partial derivative $\frac{\partial \sigma}{\partial \epsilon}$ instead of the general expression $\frac{d \sigma}{d \epsilon}$ : Morrison (5) worked principally with steels. His results indicated that all the stress values tend to rise with increased speed of testing; however, the form of the stressrate of strain curves differs. The value of the yield stress seemed to approach asymptotically, at low speeds, a definite minimum value, and rose very rapidly at the other end of the rate-of-strain scale. The plastic yield and ultimate stresses, on the other hand, seemed to suggest that the material, after yield, behaves like an extremely viscous fluid. These values did not increase so rapidly at high speeds, but they gave little indication of approaching a fixed minimum value at the lowest speeds used as was the case with the yield stress discussed above.

Jones and Moore (6) in their work on a number of metals found that the rate of strain had an appreciable effect on the tensile test data. However, with the exception of stain- 
less steel specimens, the extent of this effect might be expressed by the statement that a variation of rate of strain from $N$ per cent per minute to $2 N$ would introduce a variation not greater than $1 \%$ in the value of the yield or the tensile strength and not greater than $3 \%$ in elongation or reduction of area.

Fry (7) performed over 300 tensile tests at various speeds on a number of testing machines to study how the rate of pulling affects the yield point and tensile strength at room temperature. He observed that the tensile strength was not greatly influenced by the strain rate but that the re was a considerable effect on the yield point. His general conclusions were

1. Yield point values determined under normal testing conditions show a scatter considerably greater than can be attributed to variations in the quality of the material.

2. Yield point values tend to increase with an increase in the rate at which the test specimen is strained.

3. Yield point values increase generally in a straightline relation with the logarithm of the rate of straining. There is also some indication that for the same increase in the rate of straining, the rise in yield point is less rapid with specimens that have 8-inch gage lengths than it is with specimens 
of 2-inch gage lengths.

Austin and Steidel (8) worked with a method to deternine the dynamic tensile properties of materials at high strain rates. They founc that for most engineering materials, dynamic strength increases with increasing strain rate and decreases with increasing temperature. Under adiabatic conditions of high-speed plastic deformation experienced in impact loading, the observation was that the effects of strain rate and temperature apparently act simultaneously.

Pew experimenters have actually tried to relate the effect of strain rate to the other variables involved in tensile testing. However, Lubahn ( 9 ) has derived an equation relating stress $(\sigma)$ for plastic flow, plastic strain $(\epsilon)$, strain rate $(\dot{\epsilon})$ and temperature $(T)$. Three basic equations are utilized in the derivation.

$$
\begin{aligned}
& \epsilon=A \sigma^{\mathrm{m}} \mid \dot{\epsilon}, T \\
& \sigma=B \dot{\epsilon}^{\mathrm{n}} \mid \epsilon, T \\
& B=T(F-\ln \dot{\epsilon}) \mid \sigma, \epsilon
\end{aligned}
$$

The general expression,

$$
\sigma=c G^{T}\left(\dot{\epsilon} / \dot{\epsilon}_{0}\right) D T \epsilon^{\left(E-F T 1 n \dot{\epsilon} / \epsilon_{0}\right)}
$$

where $C, D, B, F, G$ and $\dot{\epsilon}_{0}$ are constants of the material, was then developed from the se relations. 


\section{OBJECTIVES OF THE INVESTIGATION}

The paramount purpose of this investigation was to observe the effect which an increase in the rate of loading had on the tensile properties of normal alpha uranium. Three different constant strain rates were utilized in the analysis. Observations were then made on the tensile strength, elastic modulus, yield strength at $0.2 \%$ offset, percentage elongation (in 1.5 inch gage length), percentage reduction in area and slope of the stress versus strain curve in the region of plastic flow. From the data on these properties, some considerations on how the rate of loading affected strain hardening in uranium at different temperatures could be made. In addition, special characteristics of deformation by twinning and slip in uranium could be observed. 
MATEKIAL AND APPARATUS

It has been brought out by Hueschen (10) that the properties of uranium are sensitive to orientation, which is controlled by prior heat treatment and fabrication history. Such sensitivity to orientation is due to anisotropy, ie. the properties of uranium are dependent on the crystallographic direction in which the measurement is mado.

It has further been reported by Huschen (10) and also by Kaufmann (11, p. 65) that variations in chemical composition are known to have a marked effect on the mechanical or tensile properties of uranium.

Ho1den (12, p. 66) states that uranium, like many other metals, can have a wide variation in tensile properties depending on many factors such as grain size, preferred grain orientation, previous work history, impurity content, testing procedure and testing temperature.

So it becomes necessary to define the condition of the specimen being tested and the method of testing quite careful1y, if the tensile propertles are to have any meaning at all.

\section{Material}

Mallinckrodt Chemical Works manufactured the normal alpha uranium which was utilized in the tensile tests considered for this report. The uranium was prepared by reduction from 
the salt with magnesium to a 3,400 1b. dingot. The dingot was gamma extruded to a 7-inch diameter round which was then heat treated in a salt bath for 30 minutes at $1200^{\circ} \mathrm{p}$ and alpha extruded to rods approximately $13 / 8$ inch in diameter. It was received as slugs $13 / 8$ inch in diameter by 8 inches in length.

Analysis of the impurity content is given in Table 1.

Table 1. Spectrographic and chemical analysis of impurity content in test material as furnished by fabricator

$\begin{array}{lllllllllll}\text { Blement } & \mathrm{M} n & \mathrm{~B} & \mathrm{Mg} & \mathrm{Ni} & \mathrm{Cr} & \mathrm{N} & \mathrm{H} & \mathrm{C} & \mathrm{Pe} & \mathrm{Si}\end{array}$

PPM $<10<0.10<10 \quad 14<5.12 \quad 1.3: 20$

Wt. $\%$

0.00530 .0027

The density of the material at room temperature was $19.03 \mathrm{gm} / \mathrm{cm}^{3}$.

\section{Specimen Preparation}

None of the specimens were annealed before testing $s 0$ it was important to prepare the specimens 80 that they would be as similar in grain structure as possible. This was done by first cutting the 8-inch slugs into 4-inch lengths. By cutting along two perpendicular diameters, each 4-inch 81 ug was then sawed into quarters providing the rough pieces from which the specimens were subsequently machined. Therefore, every specimen had about the same average grain structure 
since they were all made out of material equidistant from the surface of the slug.

The 4-inch specimen was prepared so that the reduced testing section at the center two inches of the specimen had a 0.357 inch diameter as recommended for tensile testing by the ASTM standards (13). The remainder of the specimen was threaded.

$1 / 2$ - 13UNC threads were cut approximately one inch long on each end of the specimen immediately after rough turning was completed and then the center 2 -inch test section was machined. By means of interchangeable carbide tips and an advance of 0.001 inch, the $0.357(+0.001,-0.000)$ inch specification was met in this test section of the specimen. A finish pass then gave the piece a smooth appearance.

The tool was fed very slowly for the duration of the machining of the specimen since uranium is spontancousiy flammable at temperatures caused by fast machining and also in order to minimize the amount of cold work affecting the piece.

\section{Testing Bülpüut}

The tensile testing of uranium, especially at higher temperatures requires a unique testing facility since this material is easily oxidized (14). The equipment used in performing the tests for this report will be described brief1y. 
Much of the apparatus was specially designed by Bohn and Murphy (15).

Test facility

Load application for the tensile tests was provided by a 60,000-1b. Baldwin-Southwark hydraulic testing machine. This was used in conjunction with a Tate-Emery load indicator, an electronic proportioning furnace controller, a high temperature vacuum test chamber, an extensometer - IVDT strain indicator, a Mosley Autograf $x-y$ recorder for 1oadstrain recording, vacuum pumping and measuring instruments and temperature indicating and recording potentiometers. A platinum resistance thermometer, wound integrally with furnace heater windings, provided temperature sensing for control. Four chromel-alumel thermocouples attached to the specimen provided temperature measurements.

A specimen was set up in the total test assembly by first having it secured in the Baldwin testing machine. With extensometer and thermocouples attached, it was then enclosed in the vacuum system where it in turn underwent thorough heating by a furnace located outside the vacuun system. With the temperature set at the correct level as seen on the recorder. straining the specimen caused the extensometer-IVDr strain indicator to be activated. The strain and load indications then were plotted on the stress-strain coordinates of the Mosley Autogiaf $x-y$ recorder and a record of the entire test 
was obtained.

\section{Test chamber}

To provide protection against oxidation, a vacuum chamber, as mentioned above (15), housed the specimen and its extensometer mechanism. This chamber was attached by means of the lower load application rod to the lower stationary cross-head of the tensile machine and thus did not affect the tare weight of loading. During loading, elongation of the chamber was permitted by means of a bellows at the top of the chamber. Pressures between 1 and $5 \times 10^{-6} \mathrm{~mm} \mathrm{Hg}$ could be realized by the pumping system which consists of a mechanical fore pump, an oil diffusion pump and a liquid nitrogen cooled cold trap. With pressures such as the se, the furnace could go to temperatures up to $1000^{\circ} \mathrm{C}$ without oxidation effects on the uranium. Only chamber components, which were primarily 316 stainless steel prevented higher temperatures.

\section{Bxtensometer - LVDr strain indicator}

The testing system utilized a inear variable differential transformer (LVDT) to transfer strain measurements through the vacuum wall of the test chamber (1.5). The movable core of the IVDT is positioned on the inside of a flexible well of the vacuum chamber and the voltage developed as this core moves gives an indication of the strain in the specimen. Of course, the core motion occurs as a result of the movement 
of the flexible we11. By means of the well, the motion was transmitted from the knife edges that are rigidly attached to the tensile specimens. Thus, strain was actually read out through the IVDT. The ac output voltage of the IVDT was rectified to dc and both load (stress), from the Tate Bmery indicator, and strain could be sensed and plotted on the Mosiey Autograf recorder. 
EXPER IMENTAL PROCEDURE AID RESULTS

In order to carry out a tensile test on normal alpha uranium, a specimen was set up with a 1.5-inch gage length between the knife edges in the apparatus previously described. Next, the vacuum system was started and when a sufficient vacuum inad been achieved, tlie furnace was turned on. The epecimen was then brouglit up to a predetermined tempirature while the system was kept evacuated properly. When the desired temperature was achieved, as recorded from the thermocouple at the center of the specimen, the tensile test could finally be performed. Bleven different temperatures in the range from room temperature to $600^{\circ} \mathrm{C}$ were utilized $\left(25^{\circ} \mathrm{C}\right.$, $80^{\circ} \mathrm{C}, 150^{\circ} \mathrm{C}, 200^{\circ} \mathrm{C}, 250^{\circ} \mathrm{C}, 300^{\circ} \mathrm{C}, 350^{\circ} \mathrm{C}, 400^{\circ} \mathrm{C}, 500^{\circ} \mathrm{C}, 550^{\circ} \mathrm{C}$ and $600^{\circ} \mathrm{C}$ ). Three different constant rates of straining were also employed at each temperature $\left(0.0400\right.$ min. ${ }^{-1}, 0.0130$ min. ${ }^{-1}$ and $0.0017 \mathrm{~min}^{-1}$ ). To maintain these rates, the operator adjusted the Baldvin machine properig over intervals. Porty tensile tests were carried out but some data on several tests were disregarded because of inoperation of some part of the apparatus.

The results of each of the forty tensile tests are reported in Table 2: The temperatures shown in this table were those 1isted on the temperature recorder. Such temperatures were therefore registered at the center of the specimens. 
Table 2. Tensile properties of normal al pha uranium

\begin{tabular}{|c|c|c|c|c|c|c|c|c|}
\hline $\begin{array}{l}\text { Test } \\
\text { no: }\end{array}$ & $\begin{array}{l}\text { Temp. } \\
\text { ( }\end{array}$ & $\begin{array}{l}\text { Strain } \\
\text { rate } \\
\left.\text { (min }^{-1}\right) \\
.\end{array}$ & $\begin{array}{l}\text { Tensile } \\
\text { strength } \\
\text { (ksi) }\end{array}$ & $\begin{array}{l}\text { Percentage } \\
\text { elongation } \\
\text { in } 1.5 \text { inch } \\
\text { gage length }\end{array}$ & $\begin{array}{l}\text { Percentage } \\
\text { reduction } \\
\text { in area }\end{array}$ & e $1 / \mathrm{m}$ & $\begin{array}{c}\text { Modulus } \\
\text { of elas- } \\
\text { ticity } \\
\left(\text { psi } x 10^{6}\right)\end{array}$ & $\begin{array}{l}\text { Yie1d } \\
\text { strength } \\
\text { at } 0.2 \% \\
\text { offset } \\
\text { (ksi) }\end{array}$ \\
\hline $\begin{array}{l}1 \\
2 \\
3 \\
4 \\
5 \\
6 \\
7 \\
8 \\
9 \\
10 \\
11 \\
12 \\
13 \\
14 \\
15 \\
16 \\
17 \\
18 \\
19 \\
20\end{array}$ & $\begin{array}{r}25 \\
25 \\
25 \\
80 \\
80 \\
80 \\
150 \\
150 \\
150 \\
150 \\
150 \\
150 \\
200 \\
200 \\
200 \\
200 \\
250 \\
250 \\
250 \\
250\end{array}$ & $\begin{array}{l}0.0130 \\
0.0400 \\
0.0017 \\
0.0130 \\
0.0400 \\
0.0017 \\
0.0130 \\
0.0017 \\
0.0130 \\
0.0400 \\
0.0130 \\
0.0017 \\
0.0130 \\
0.0400 \\
0.0017 \\
0.0400 \\
0.0130 \\
0.0400 \\
0.0400 \\
0.0017\end{array}$ & $\begin{array}{l}95.6 \\
98.2 \\
93.5 \\
96.8 \\
97.7 \\
95.1 \\
74.8 \\
78.4 \\
74.4 \\
79.0 \\
74.6 \\
76.5 \\
65.7 \\
65.2 \\
65.3 \\
64.2 \\
52.0 \\
52.4 \\
55.2 \\
50.8\end{array}$ & $\begin{array}{r}8.7 \\
6.7 \\
8.7 \\
26.7 \\
28.1 \\
18.0 \\
27.3 \\
31.7 \\
31.7 \\
27.7 \\
29.5 \\
28.8 \\
31.1 \\
31.3 \\
29.6 \\
28.7 \\
31.3 \\
28.3 \\
22.3\end{array}$ & $\begin{array}{r}11.2 \\
9.1 \\
9.6 \\
22.1 \\
20.1 \\
15.0 \\
29.3 \\
27.8 \\
31.1 \\
37.6 \\
29.3 \\
49.7 \\
48.5 \\
44.8 \\
37.6 \\
52.4 \\
59.7 \\
52.0 \\
45.2\end{array}$ & $\begin{array}{l}0.355 \\
0.299 \\
0.284 \\
0.319 \\
0.300 \\
0.306 \\
0.239 \\
0.301 \\
0.264 \\
0.257 \\
0.253 \\
0.232 \\
0.222 \\
0.246 \\
0.204 \\
0.230 \\
0.198 \\
0.195 \\
0.223 \\
0.182\end{array}$ & $\begin{array}{l}25.2 \\
27.5 \\
29.1 \\
20.8 \\
30.3 \\
27.5 \\
24.3 \\
26.3 \\
20.7 \\
21.7 \\
26.1 \\
24.4 \\
20.2\end{array}$ & $\begin{array}{l}42.0 \\
40.5 \\
\\
37.6 \\
\\
31.7 \\
\\
34.2 \\
34.7 \\
32.6 \\
31.6 \\
33.7 \\
30.2 \\
31.4 \\
29.9 \\
30.1\end{array}$ \\
\hline
\end{tabular}


Tab1e 2. (Continued)




The rate of loading was defined by that strain rate found in timing the progression of the $x-y$ recorder as it plotted the stress-strain curve.

The tensile strength was determined by reading the maximum position of the hand on the load indicator. A plot of tensile strength versus temperature for the three different rates of loading is shown in Pigure 1. Pigure 2 displays tensile strength versus strain rate with temperature as the parameter.

Percentage elongation of a specimen for a 1.5-inch gage length was calculated by measuring the distance between the knife edge maxks for the broken specimen and comparing this length to the original 1.5-inch gage length. Pigure 3 displays plots of percentage elongation (in 1.5 inch gage length) versus temperature for the three rates of straining. Rigure 4 then shows this percentage elongation as a function of etrain rate for various temperatures up to $600^{\circ} \mathrm{C}$.

The calculation of percentage reduction in area for the specimens was made from a measurement of the necked down area of the broken specimens as compared to the original crosssectional area. If the necked down region of the broken specimen was oval-shaped, an average of the major and minor axes was used to find the reduced area. Of course, the original area of the test portion of the specimen was 0.1 square inch based on a 0.357 inch diameter. Figure 5 is a 


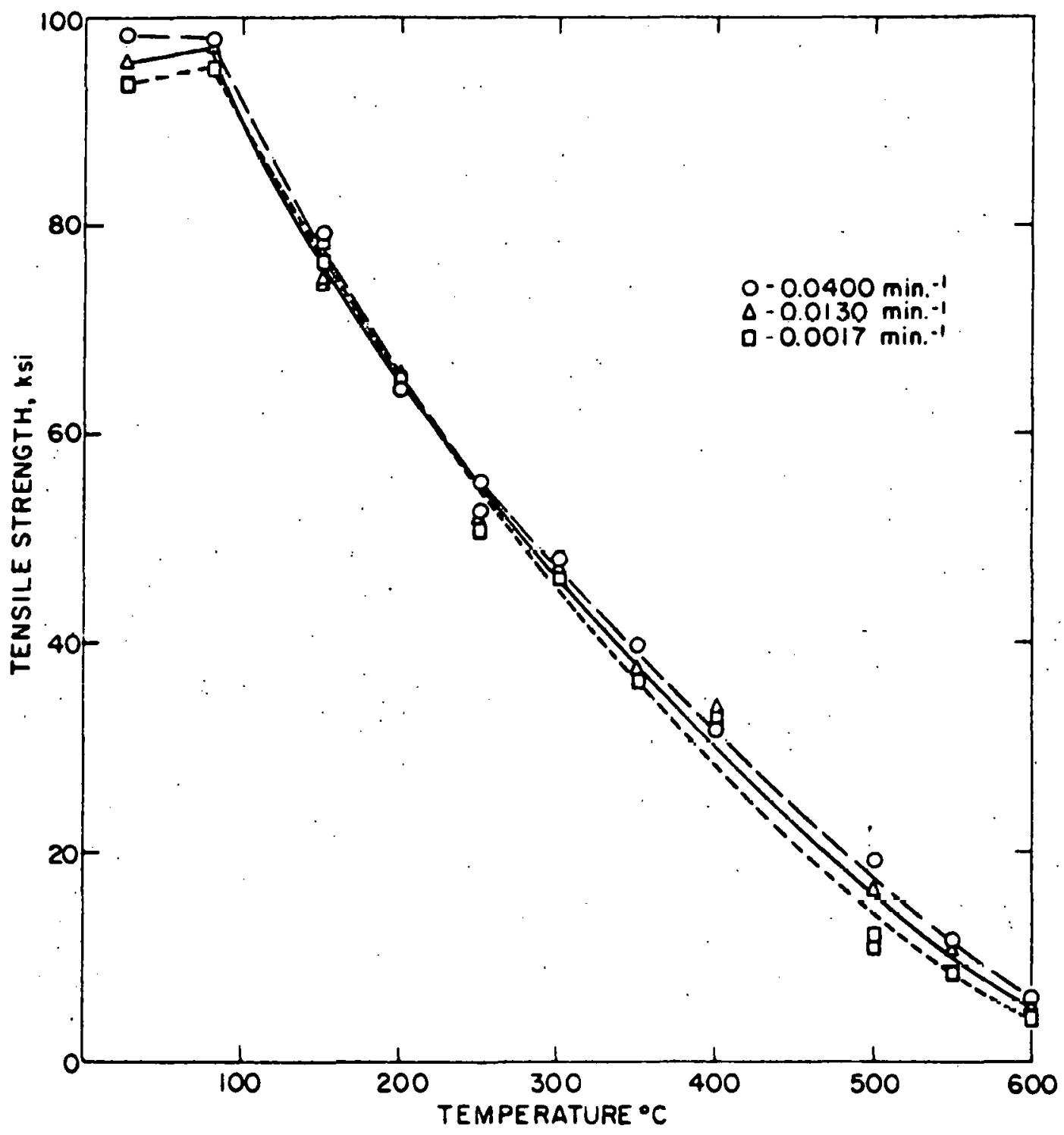

Figure 1. Tensile strength as a function of temperature for three different rates of loading 


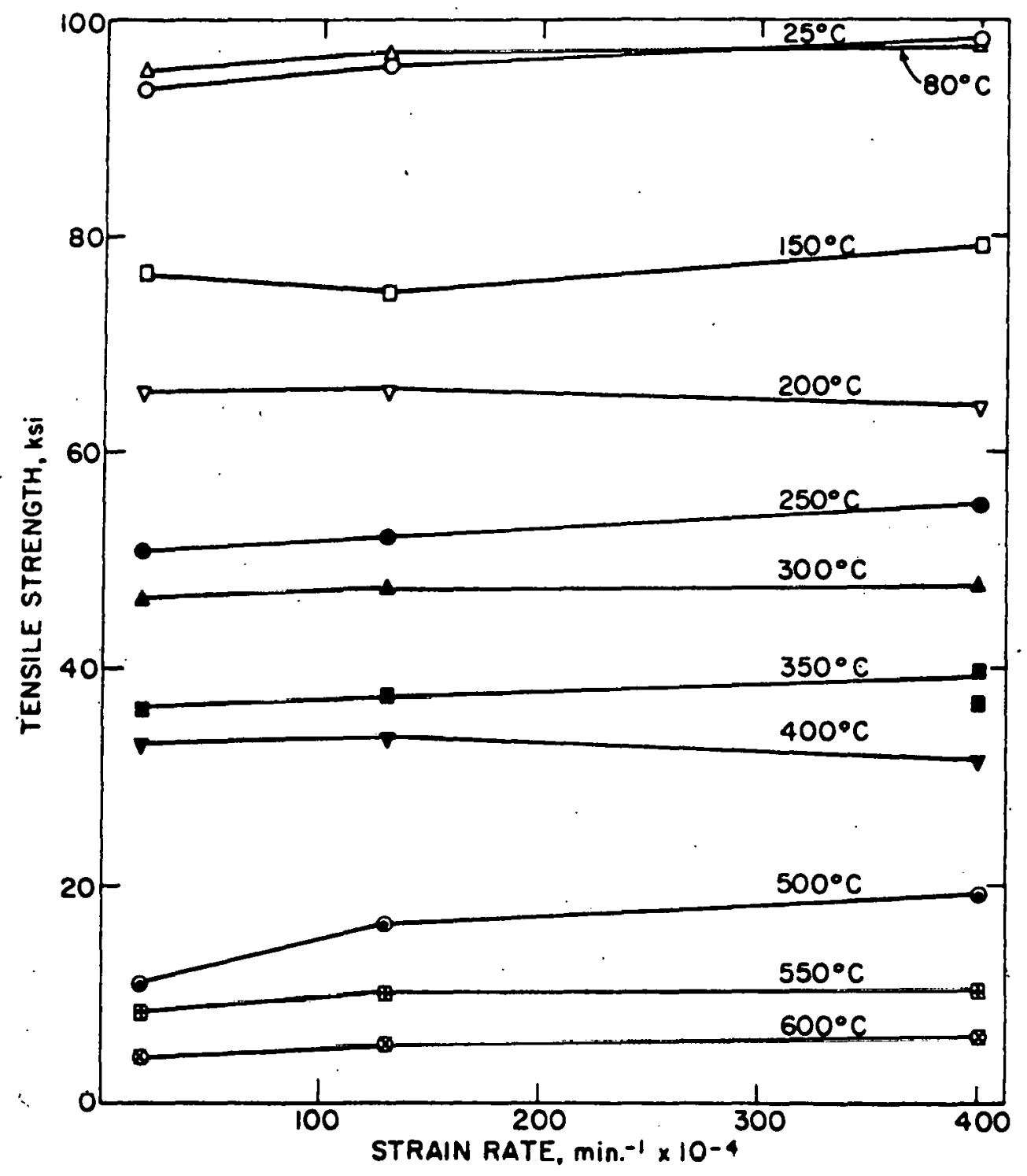

Bigure 2. Variation of tensile strength with rate of losding for temperatures from $25^{\circ} \mathrm{C}$. to $600^{\circ} \mathrm{C}$ 


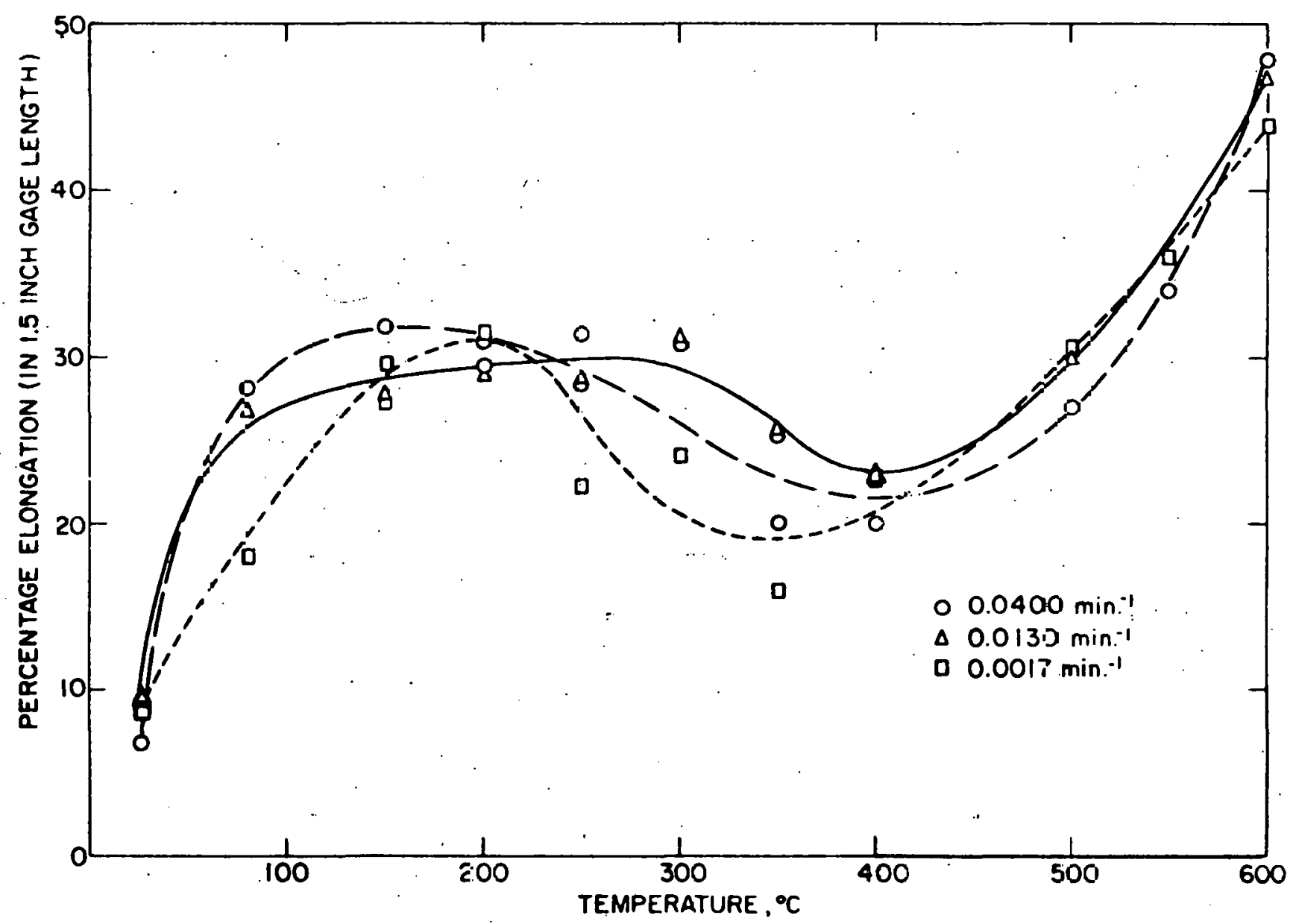

$\stackrel{N}{N}$

Pigure 3. Percentage elongation as a function of temperature for three different rates of loading 


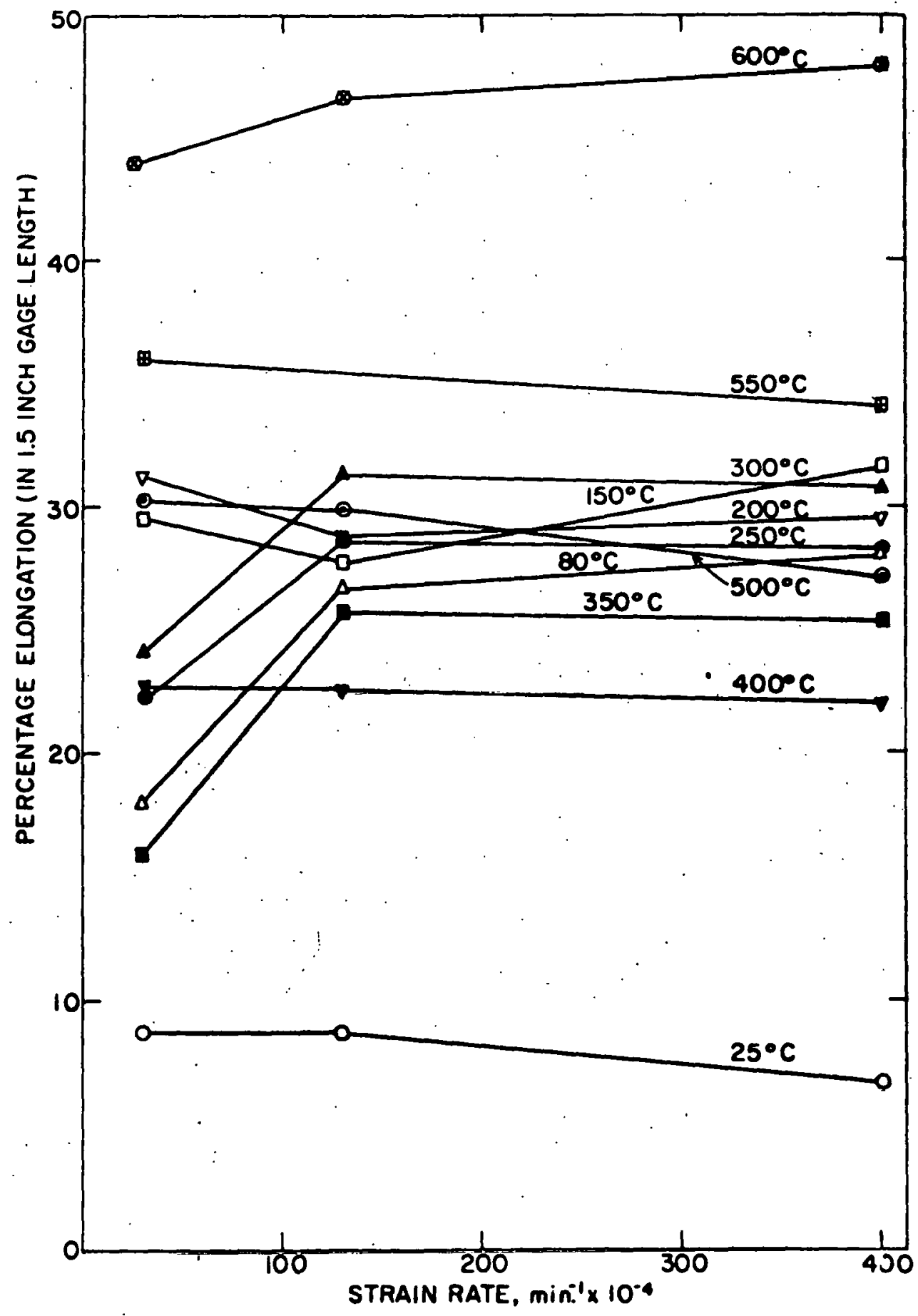

Pigure 4. Variation of percentage elongation with rate of loading for temperatures from $25^{\circ} \mathrm{C}$ to $600^{\circ} \mathrm{C}$ 
a graph of percentage reduction in area versus temperature for the three rates of loacing and Figure 6 is that same recuction versus strain rate for temperatures in the range of room temperature to $600^{\circ} \mathrm{C}$.

By locating, on $10 \mathrm{~g}$ paper, the straight line portion of the stress-strain curve which obeyed the formula $E=A 0^{m}$, $m$, or rather $1 / m=\frac{\Delta \ln \sigma}{\Delta \ln E}$ can be calculated. $1 / m$ versus temperature for the three rates of loading is shown in Figure 7. To illustrate the rate of loading influence, $1 / \mathrm{m}$ versus strain rate is plotted in Figure 8 for different temperatures which were considered.

Though it is very difficult to establish the modulus of elasticity from a stress-strain curve for uranium $(10,12$, 16), since the initial portion of the curve is not linear, some approximate values were obtained. The values of the modulus were detcrmined by calculating the slope of the straight line portion of the stress-strain curve. If the plot appeared to have any initial straight line portion at all, this was chosen to be used in the calculations. The values thus obtained were plotted versus temperature for each of the three rates of loading and can be seen in Pigure 9. The modu1 is of elasticity versus strain rate plot in Figure 10 shows the influence of the rate of loading on the modulus values at selected temperatures. 


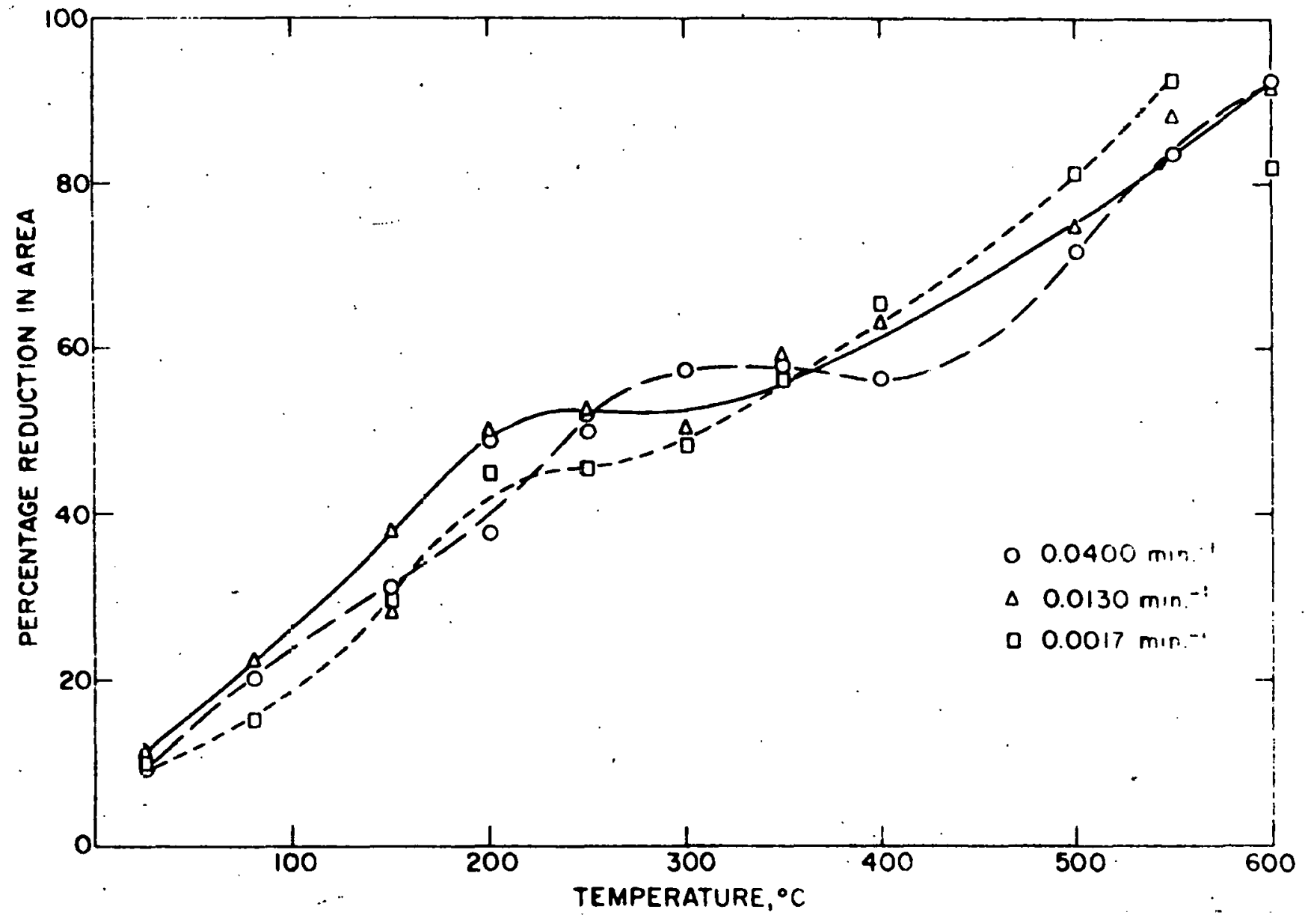

Pigure 5. Percentage reduction in area as a function of temperature for thrce different rates of loading 




Figure 6. Variation of percentage reduction in area with rate of loading for temperatures from $25^{\circ} \mathrm{C}$ to $600^{\circ} \mathrm{C}$ 


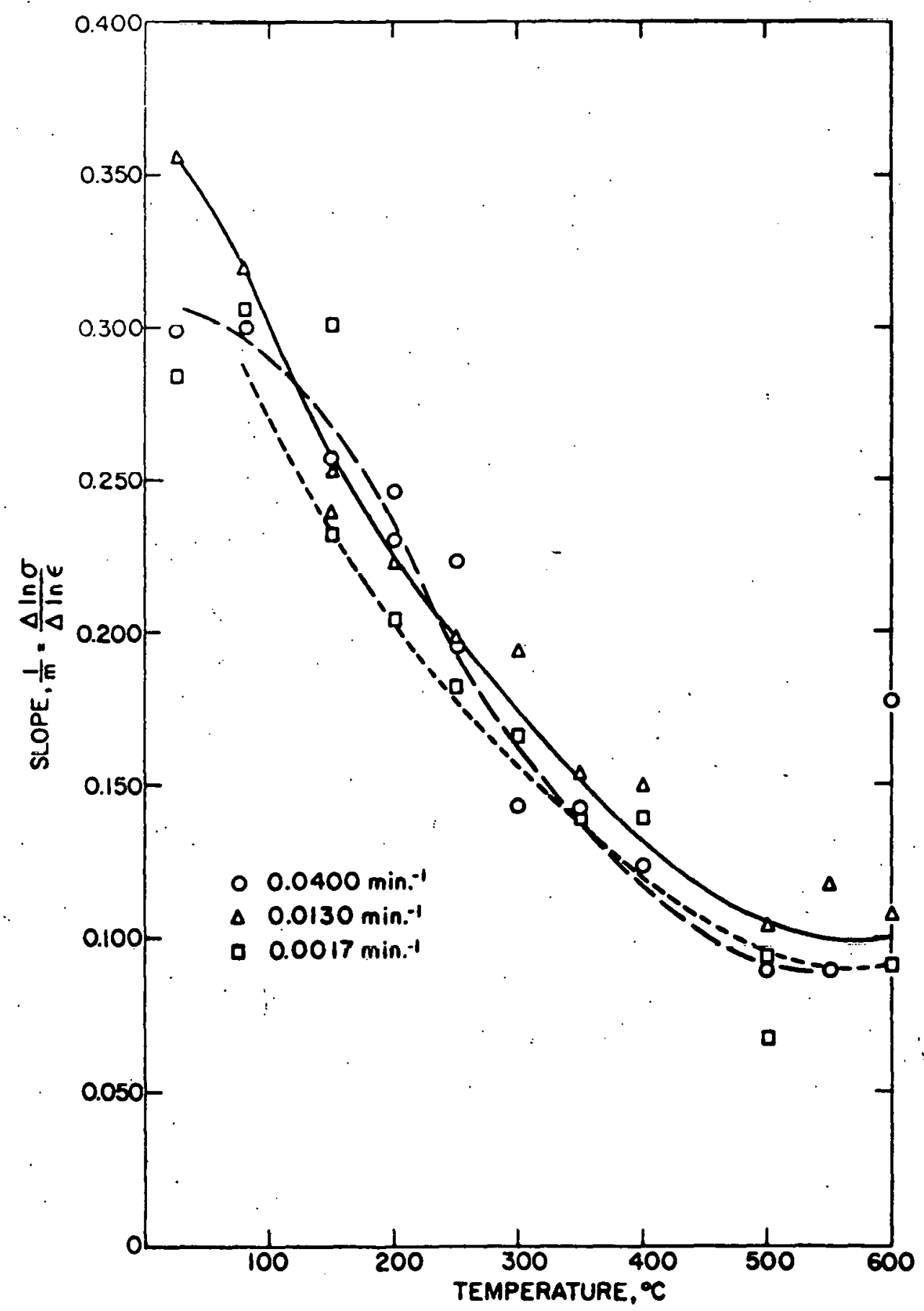

Pigure 7. Slope of the stress-strain curve for plastic flow as a function of temperature for three different rates of loading 


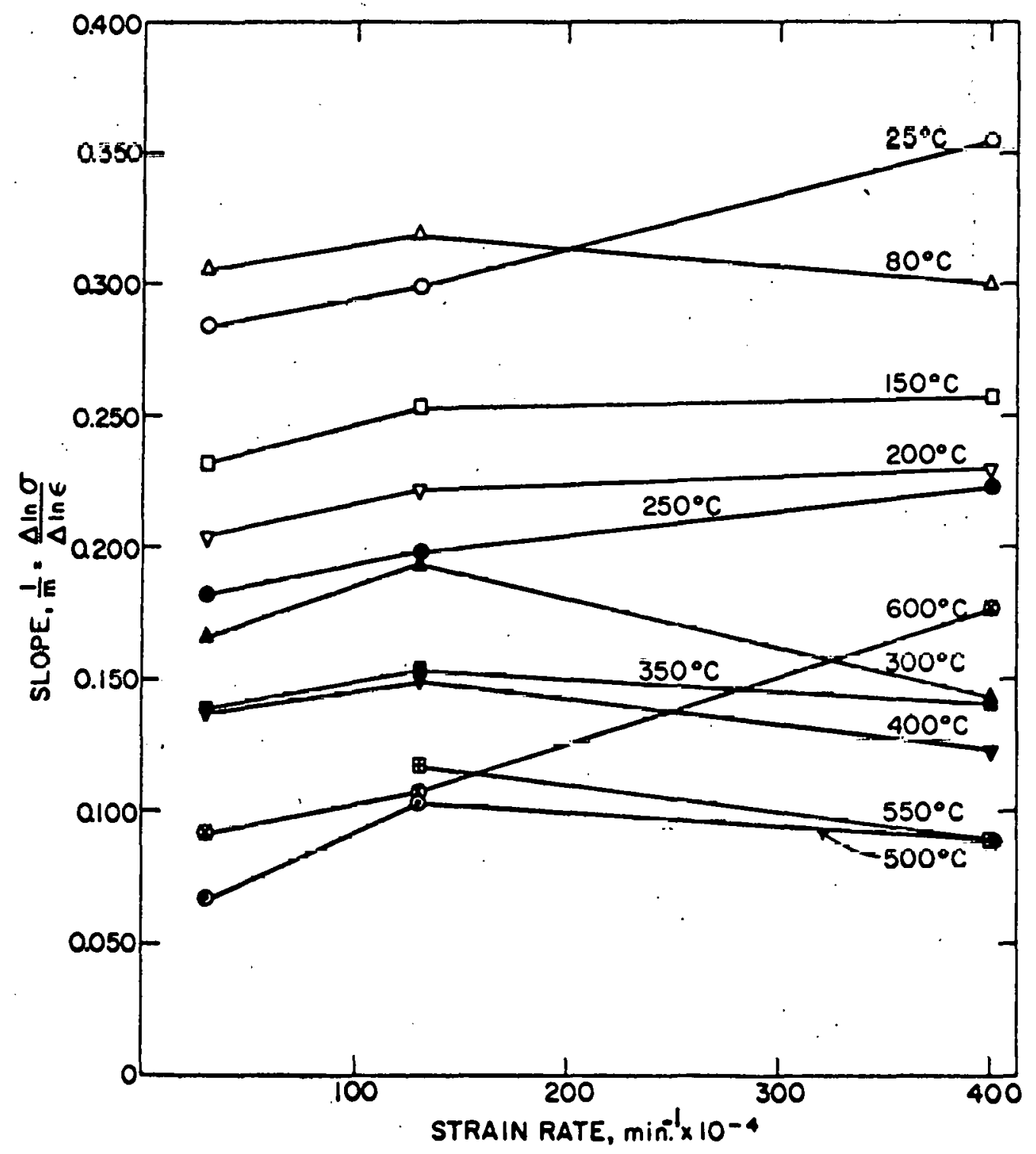

Figure 8. Variation of the stress-strain curve for plastic flow with the rate of loading for temperatures from $25^{\circ} \mathrm{C}$ to $600^{\circ} \mathrm{C}$ 


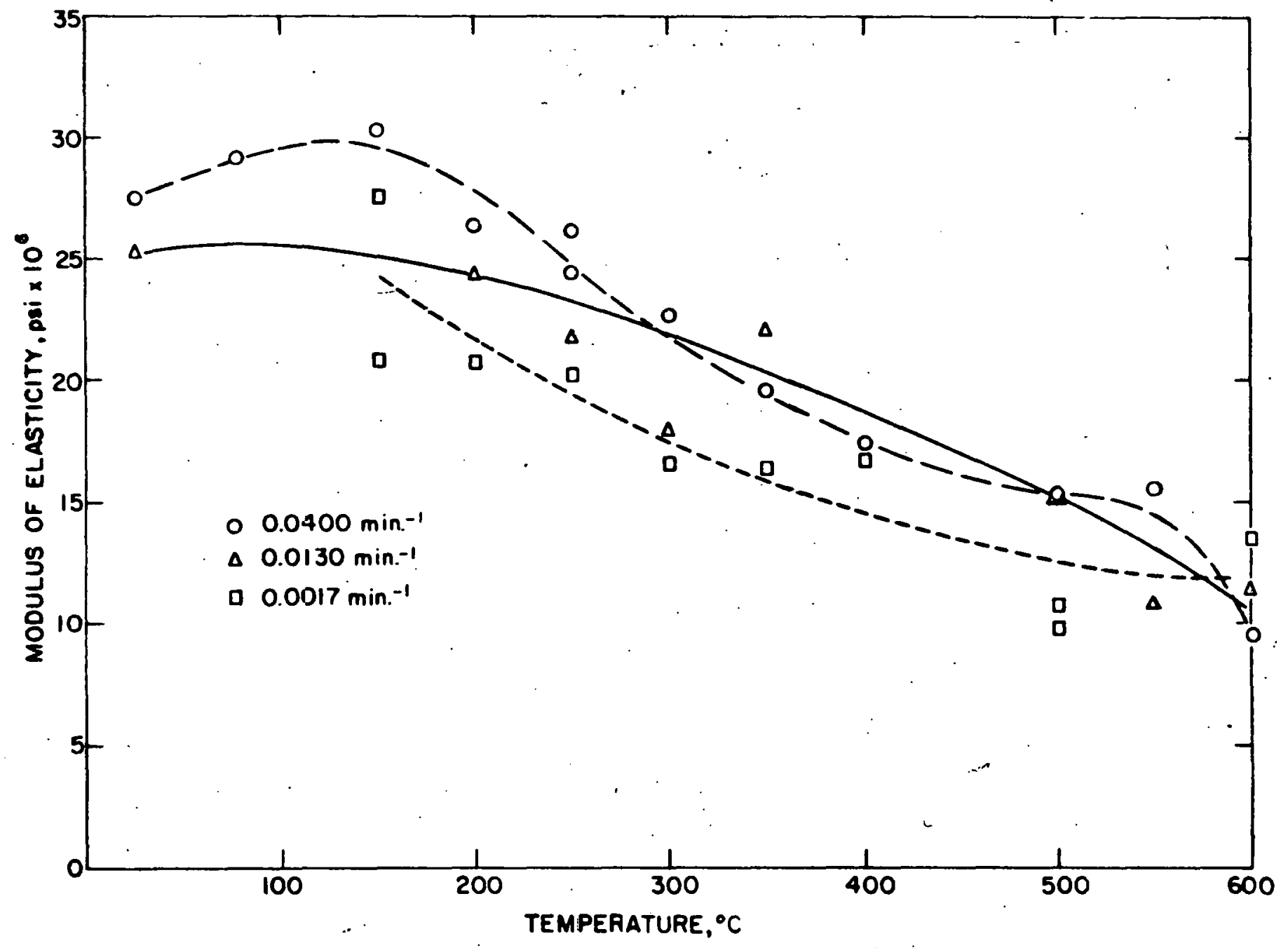

Pigure 9. Modulus of elasticity as a function of temperature for three different rates of loading 


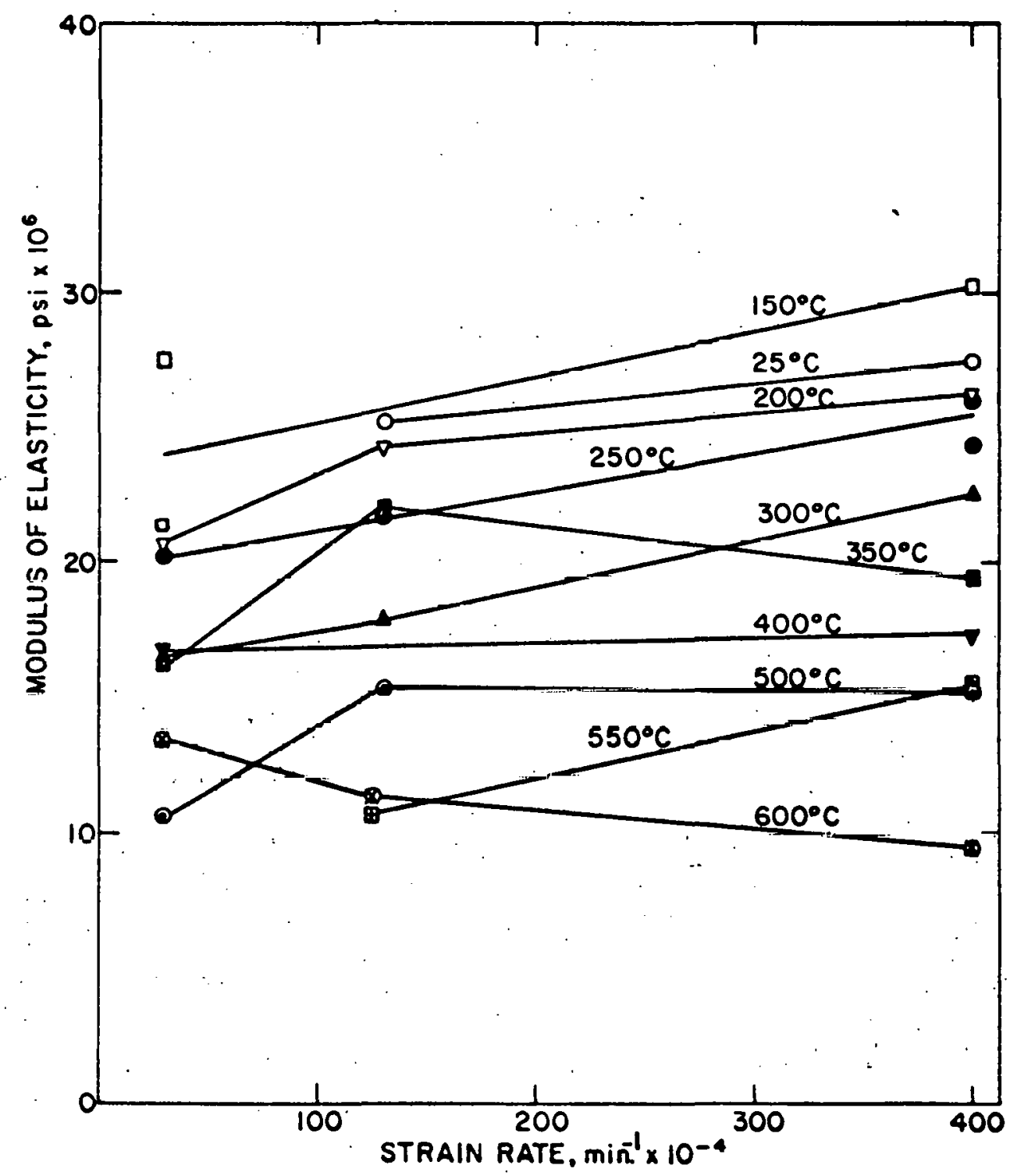

Figure 10. Variation of the modulus of elasticity with rate of loading for temperatures from $25^{\circ} \mathrm{C}$ to $600^{\circ} \mathrm{C}$ 
The yield strength at $0.2 \%$ offset was located in each of the tests for which a modulus of elasticity had been determined. The yield strength was evaluated at $0,2 \%$ offset in order to be certain that the material had actually undergone permanent deformation and in accordance with ASTM specifications. Figure 11 is a graph of yield strength ( $0.3 \%$ offset) as a function of temperature for the three rates of 10ading. However, the rate of loading effect on the rield strength can be observed more clearly in Plgure 12 where yleld atrength versus strain rate 18 plotted with temperature as the parameter.

Pigures 13, 14 and 15 are 108 plote of stress veŕsus strain with a parameter of temperature where each graph was plotted for a different rate of loading. The portion of the curves that obeys the formula $E=A$ ol is indicated in each of the figures.

A $10 \mathrm{~g}$ plot of stress versus strain is presented in PIgure 16 for temperatures in the $35^{\circ} \mathrm{C}$ to $600^{\circ} \mathrm{C}$ range and for certain definite strains at these temperatures.

Pigures 17, 18 and 19 were drawn to display the original stress-strain curves out to a straln of $20 \times 10^{-3}$. Thus, they are the actual results of the experimental work. Bach figure shows the curves for one particular rate of loading only, with temperature as a parameter.

Pigures 20, 21 and 22 are graphe of etrese versus etraln 


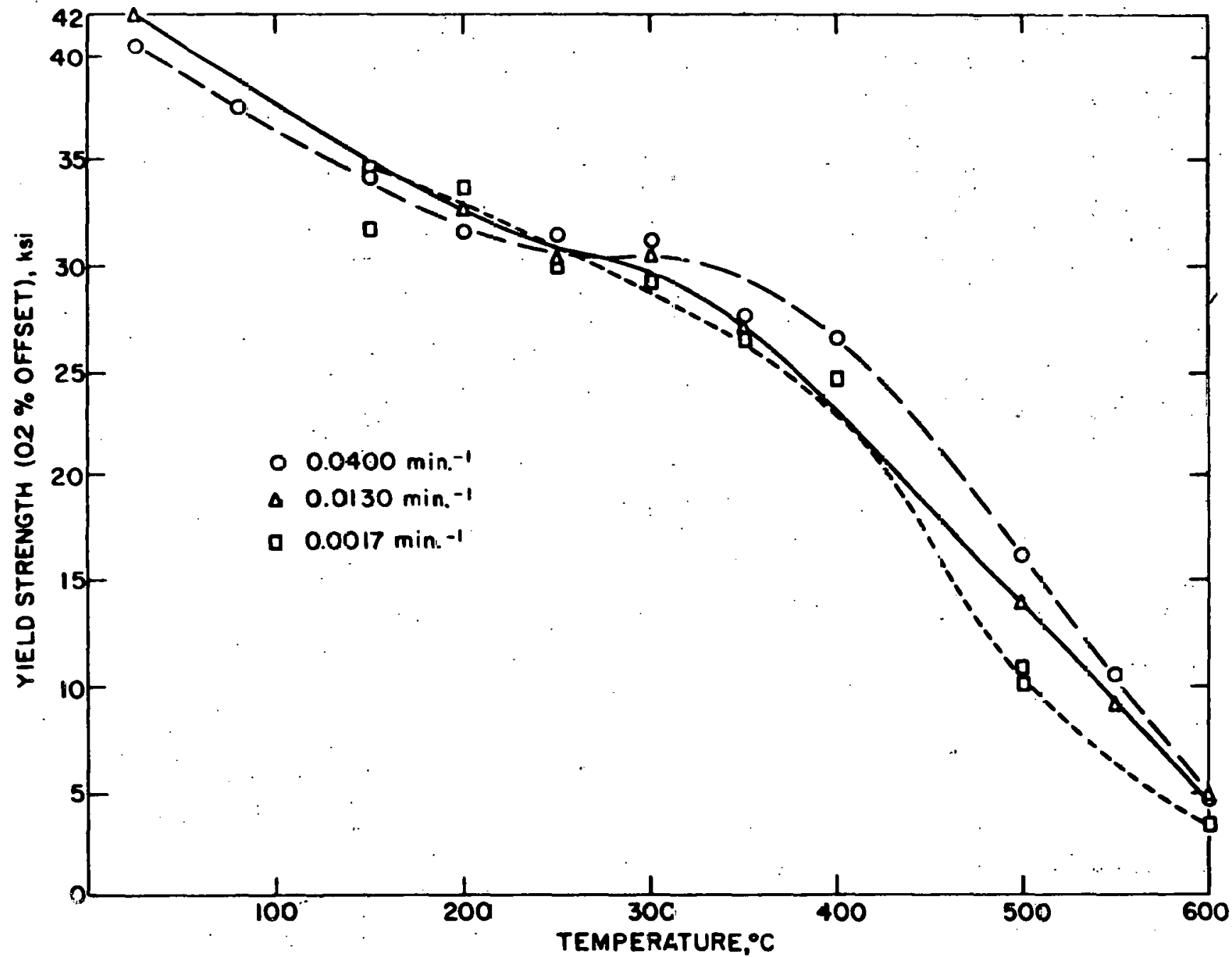

Pgure 11. Yield strength as a function of temperature for three different rates of loading 


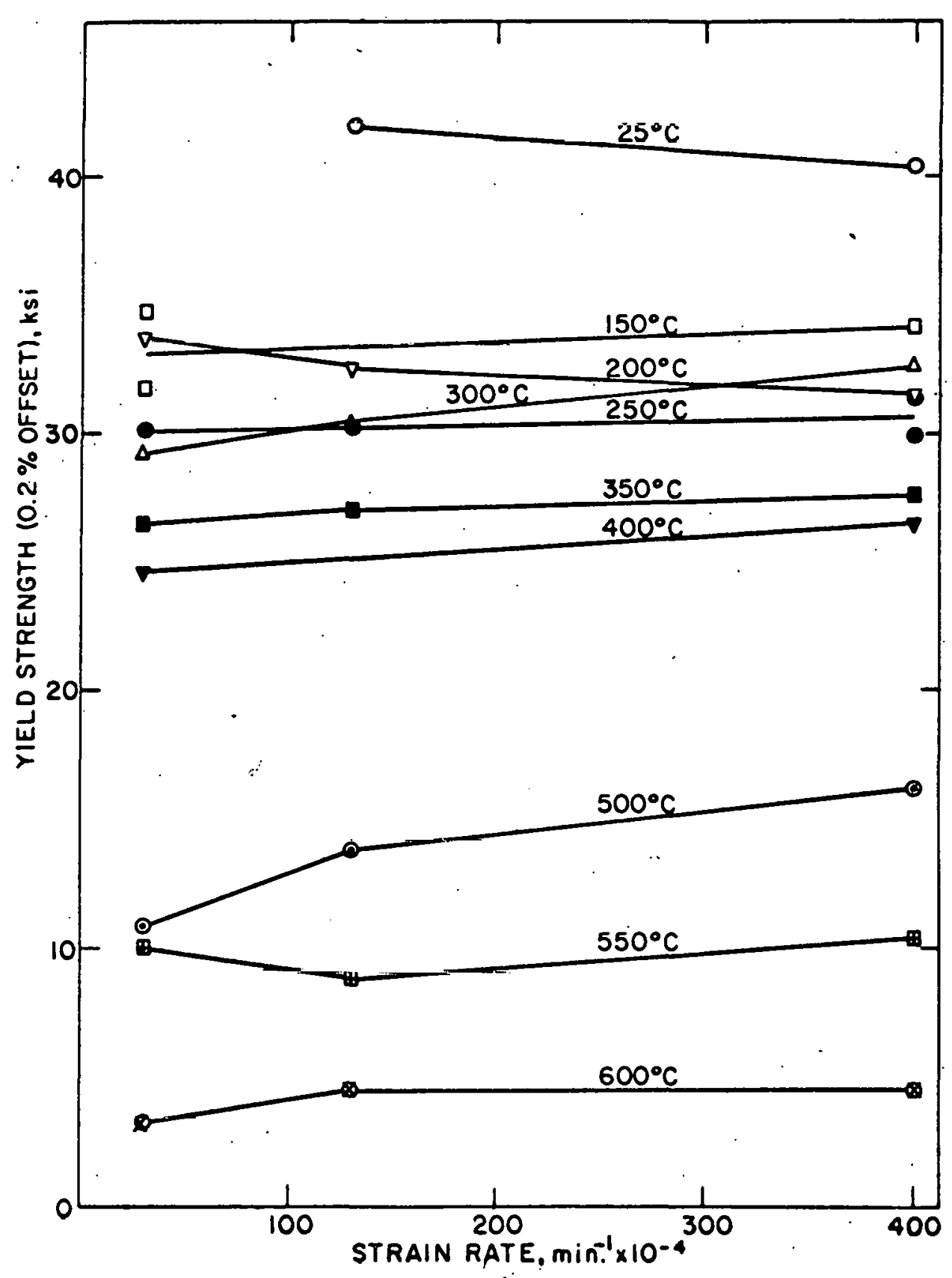

Figure 12. Variation of the yicld strength with rate of loading for temperatures from $25^{\circ} \mathrm{C}$ to $600^{\circ} \mathrm{C}$ 


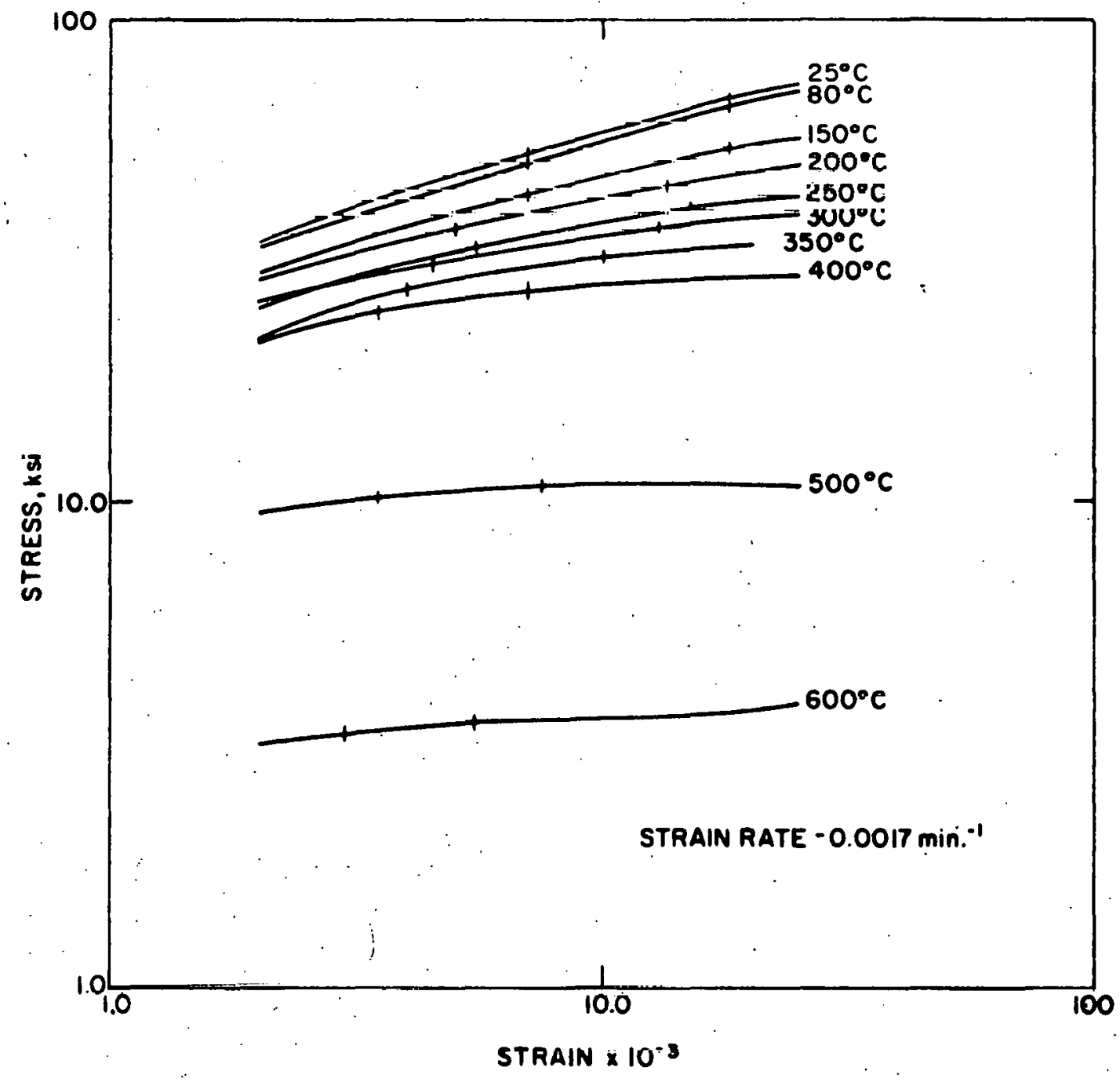

Pigure 13. Log plot of stress versus strain for the lowest rate of loading at temperatures from $25^{\circ} \mathrm{C}$ to $600^{\circ} \mathrm{C}$ 


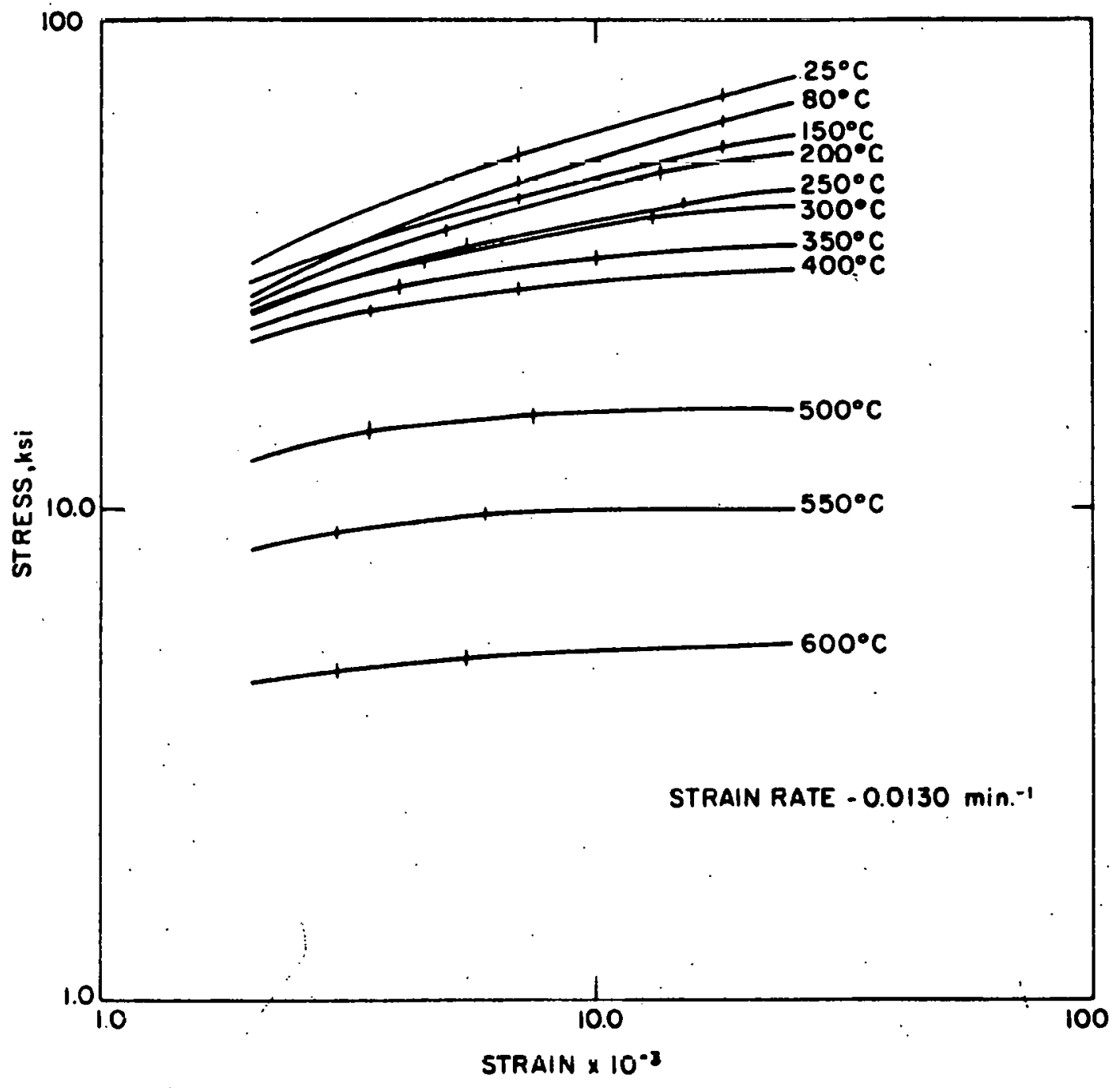

Figure 14. Log plot of stress versus strain for the medium rate of loading at temperatures from $25^{\circ} \mathrm{C}$ to $600^{\circ} \mathrm{C}$ 


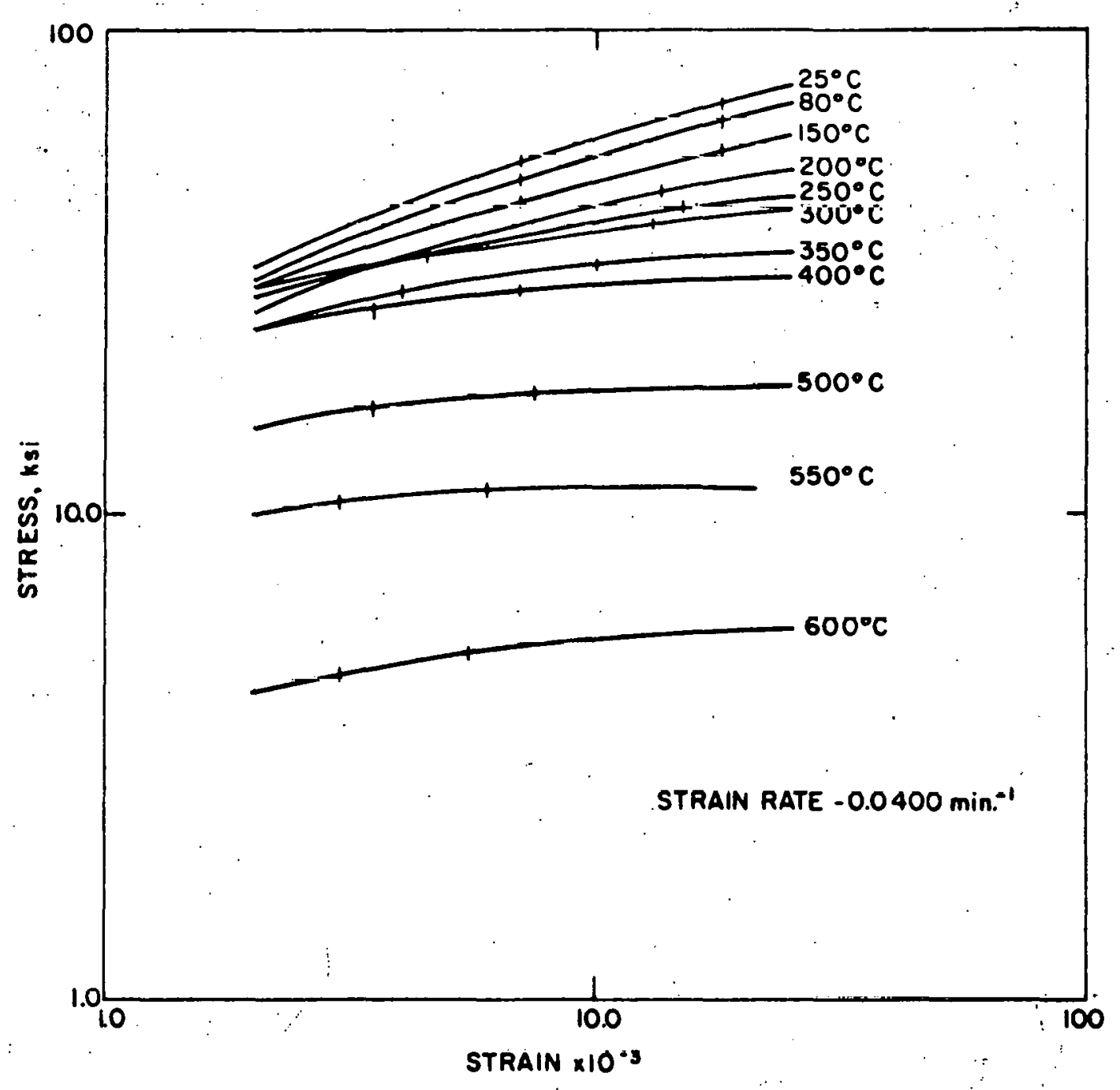

Pigure 15. Log plot of stress versus strain for the highest rate of $10 a d i n g$ at temperatures from $25^{\circ} \mathrm{C}$ to $600^{\circ} \mathrm{C}$ 


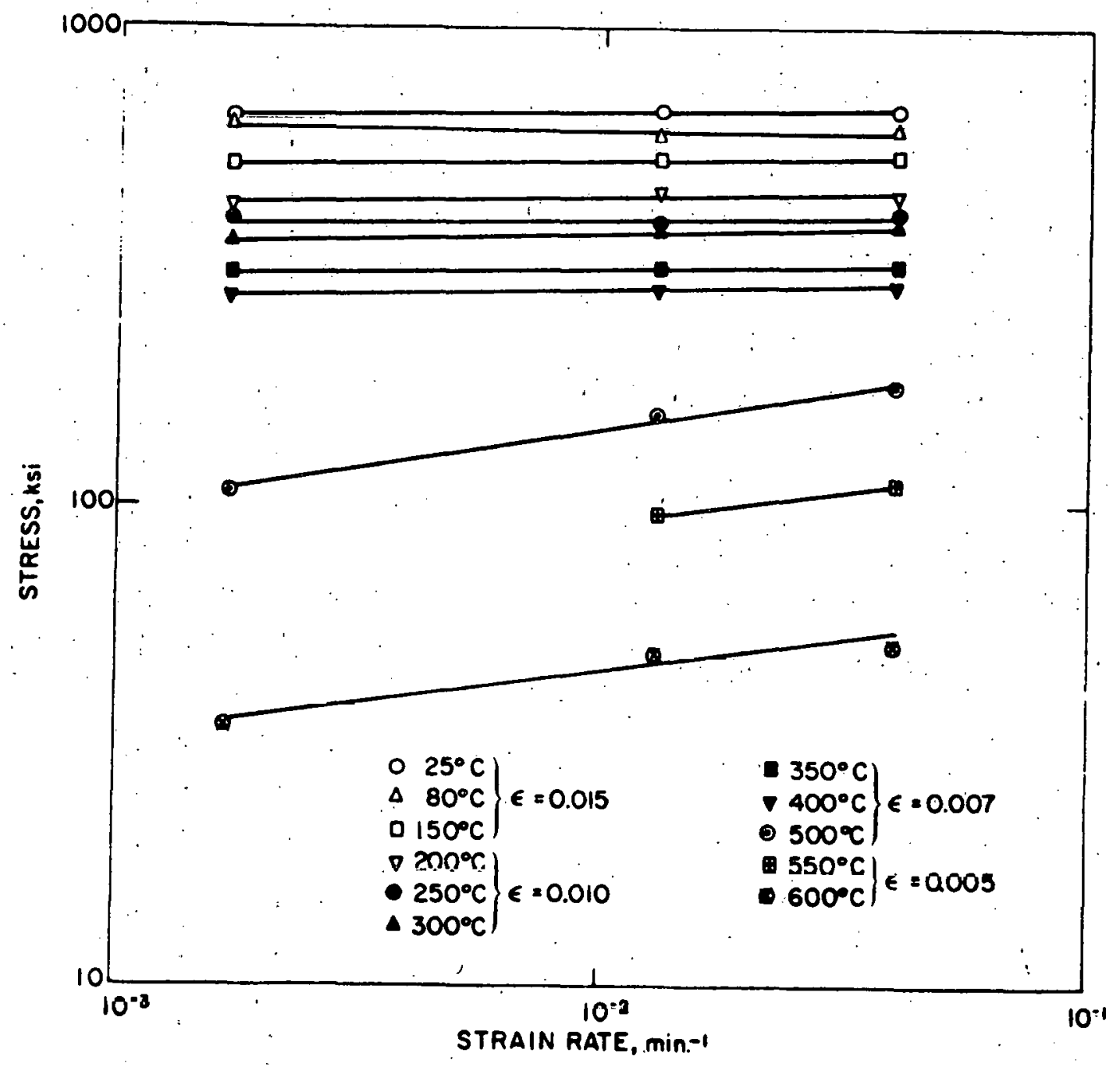

Pigure 16. Stress as a function of strain rate at certain strains for temperatures from $25^{\circ} \mathrm{C}$ to $600^{\circ} \mathrm{C}$ 




Pigure 17. Stress-strain curves over range of temperatures for lowest rate of loading 


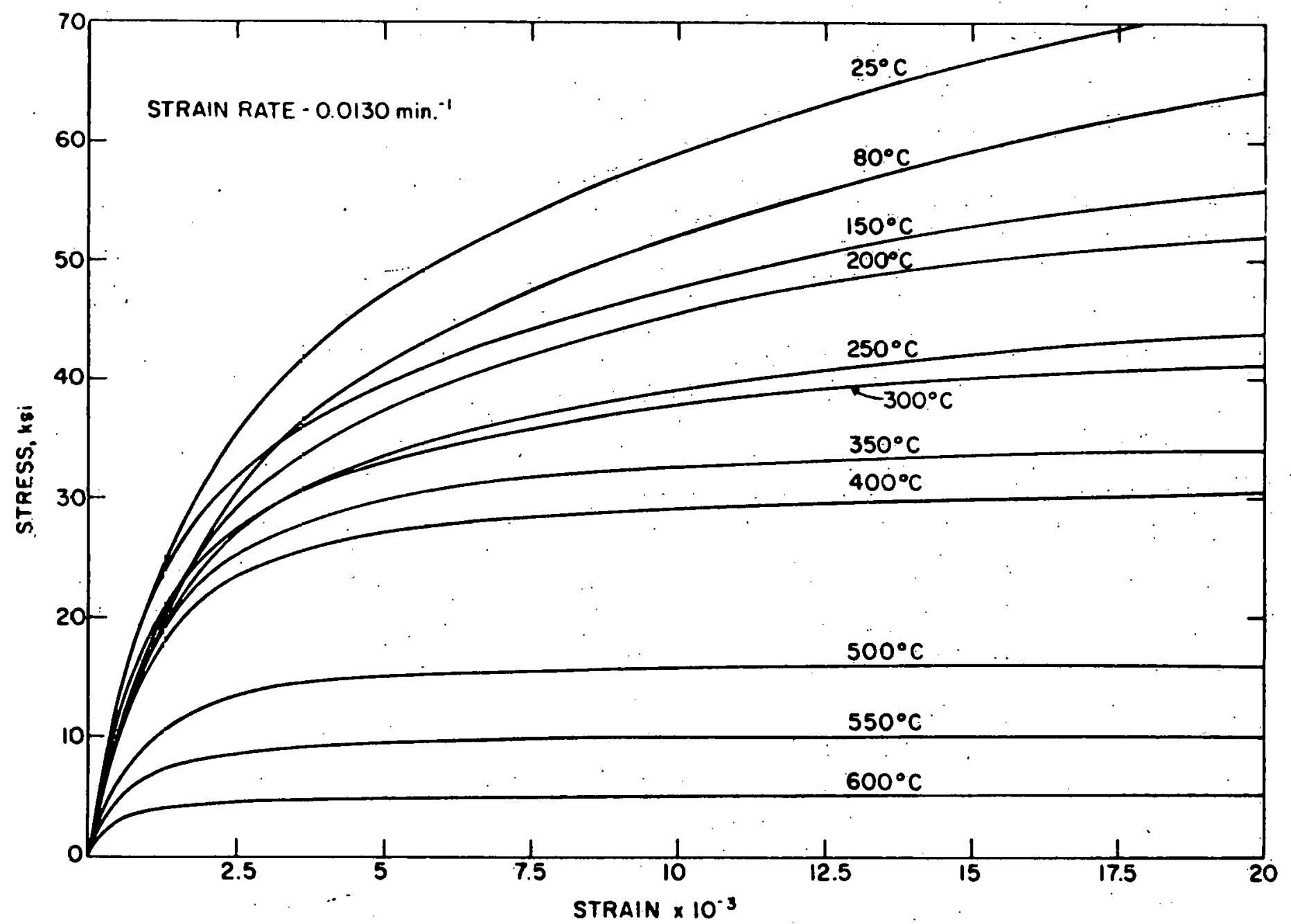

Pigure 18. Stress-strain curves over range of temperatures for medium rate of loading 


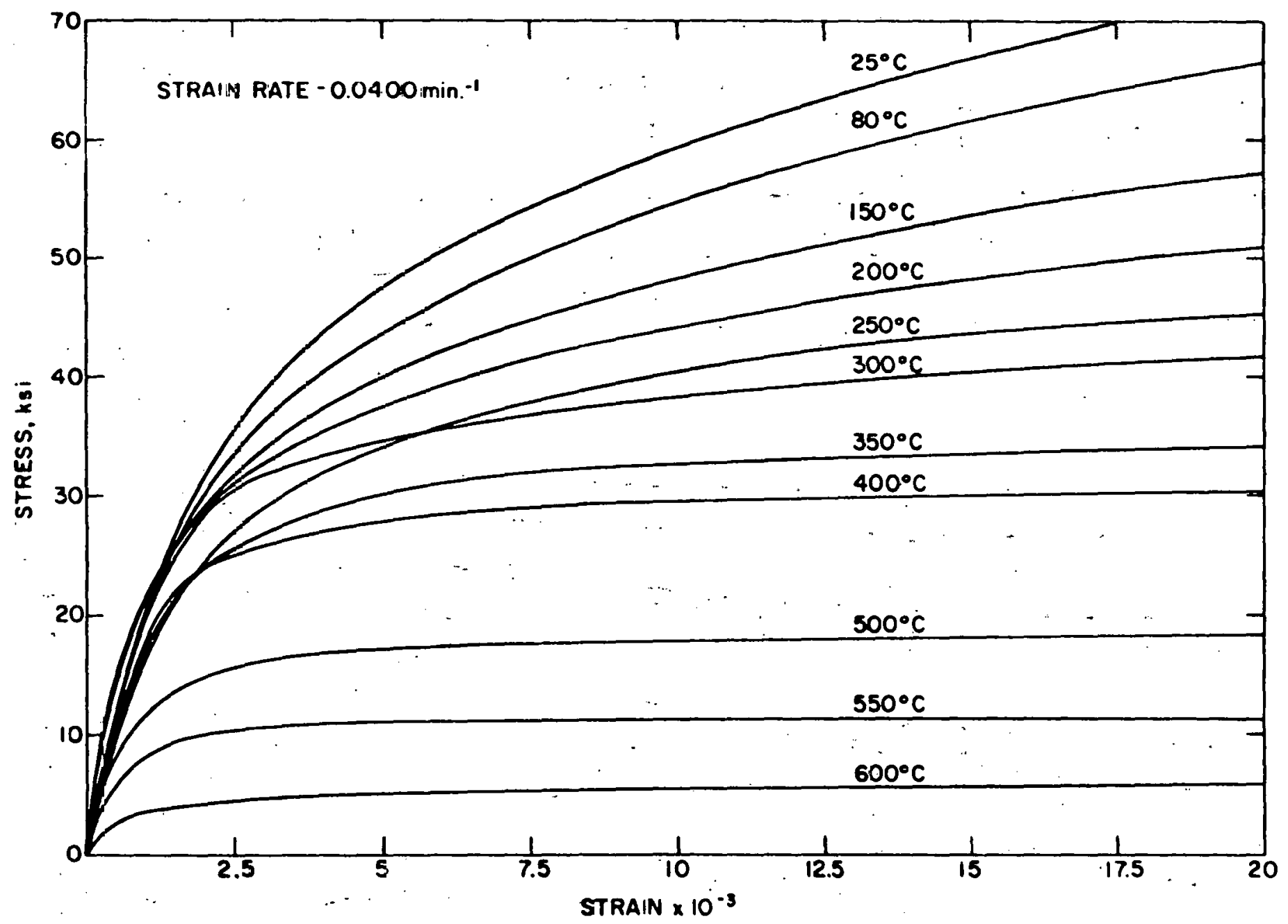

Figure 19. Stress-strain curves over range of temperatures for highest rate of loading 




Pigure 20. Stress-strain curves for various rates of loading at $150^{\circ} \mathrm{C}$ 


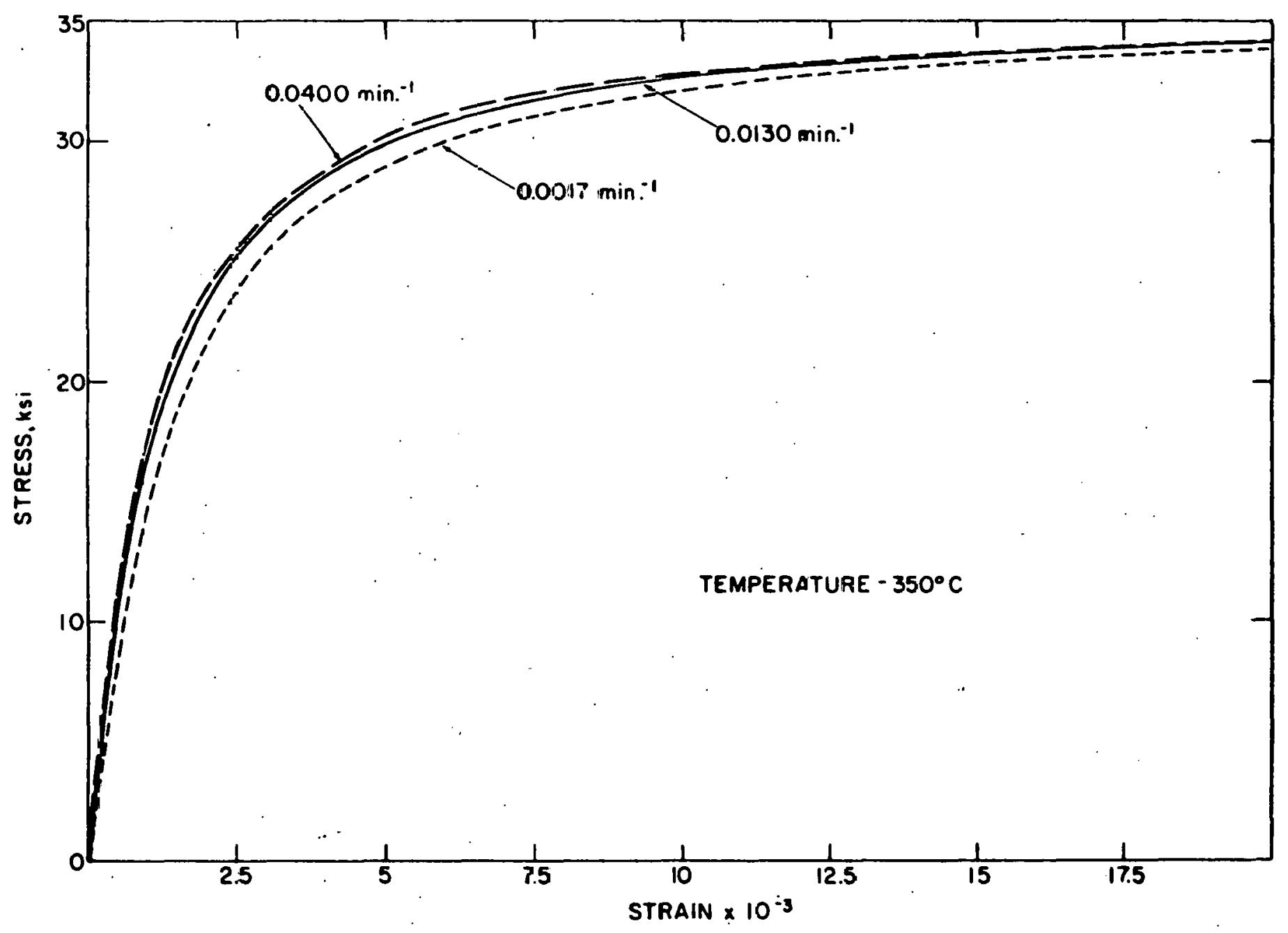

Migure 21. Stress-strain curves for varlous rates of loading at $350^{\circ} \mathrm{C}$ 


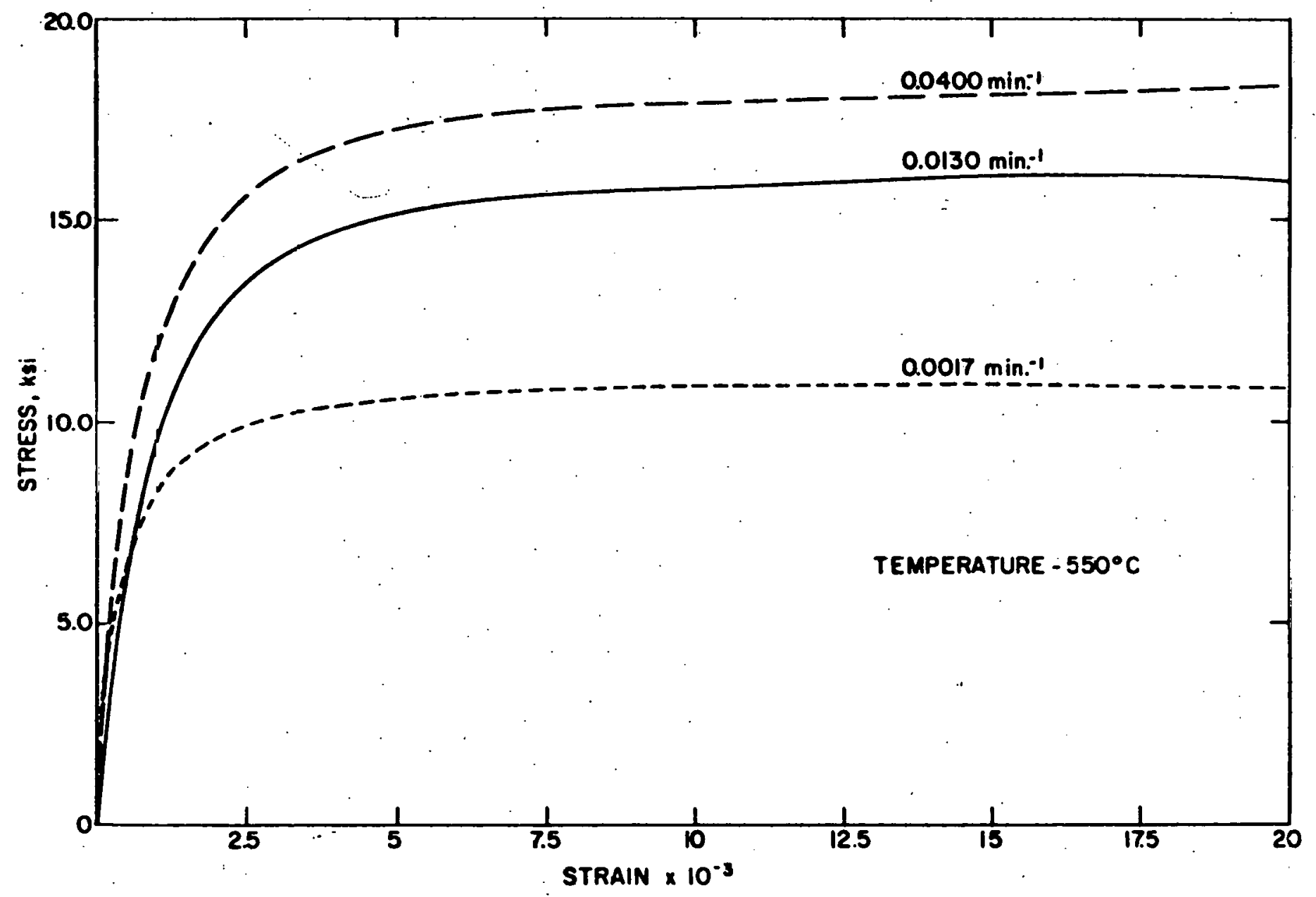

$\stackrel{\leftrightarrow}{\omega}$

P1gure 22. Stress-strain curves for various rates of loading at $550^{\circ} \mathrm{C}$ 
where rate of loading is the parameter. These curves are also taken from the original stress-strain diagrams as indicated on the $x-y$ recorder. Pigure 20 is plotted for a temperature of $150^{\circ} \mathrm{C}$, Figure 21 for $350^{\circ} \mathrm{C}$ and Pigure 22 for $550^{\circ} \mathrm{C}$. Several typical original stress-strain curves have been placed in the Appendix for the purpose of illustration, but the important portion of these original curves has already been included in pigures 23, 24 and 25. 


\section{DISCUSSION OP RESULTS}

As a result of the tensile tests which were performed on normal alpha uranium, the conclusion was made that the tensile properties of this material are affected by the rate of loading. However, the extent of the influence of the rate of loading is not nearly as great as the effect of temperature on the tensile properties. This should be obvious from a study of Pigures 1 - 22. The specific properties displayed in these figures are discussed individually below.

The tensile strength of uranium decreases with increasing temperature as observed in Pigure 1. Previous analyses on uranium $(10,12,17,18)$, have resulted in data which are generally comparable to this with the exception of the initial portion of the curve. Few experimenters have observed the anomaly in the region of $80^{\circ} \mathrm{C}$ for uranium because they have not considered it important to make a test between room temperature and $100^{\circ} \mathrm{C}$. Thus, most tensile strength versus temperature curves do not show a deviation at this point. However, such an anomaly in uranium has been observed previously bỳ Bernard and Coureau (19) and is significant since it seems to affect many of the tensile properties of the material at this temperature. The tensile strength of uranium is as high or higher, depending on the rate of loading, at $80^{\circ} \mathrm{C}$ as it is at $25^{\circ} \mathrm{C}$ (Figure 1). Above this temperature however, the 
tensile strength decreases with increasing temperature as was previous1y mentioned.

It should be noted that the test with the lowest rate of loading appears to have the lowest tensile strength. This can be observed more clearly in Pigure 2. An increase in rate of loading or strain rate generally causes an increase in tensile strength for any material considered, especially at higher temperatures $(1,3,5)$.

There are several interesting areas to study in the curves of Pigures 3 and 5. The percentage elongation of uranium, for all gage lengths, characteristically increases quickly before leveling off in its plot while the percentage reduction in area increases almost steadily $(10,12,17,19,18)$.' The reason that the curves take such shapes is rather easily explained. In the range near room temperature the deformation seems to be quite uniform over the entire reduced section of the specimen but as the temperature is increased, necking down occurs and the elongation is then localized more to the necked region. Thus, a definite break will occur in the elongation curve when localized necking down is initiated. However, the reduction of area plot will not be affected nearly as much since it is based on necking down of the specimen from the start. So in the region of $60^{\circ} \mathrm{C}$ to $70^{\circ} \mathrm{C}$, a brittle transition seems to take place in uranium (12, p. 109), as displayed on 
the percentage elongation versus temperature curve. The material is much more brittle at room temperature than it is at higher temperatures. Holden (12, p. 109) adds that this transition temperature in uranium is a function of impurity content and that it also may be caused in part by the high stresses resulting from the twinning mode of deformation.

Since the subject has been introduced, it should be pointed out that twinning is certain1y involved in the oignificant deviation from the smooth plot observed in the region of $350^{\circ} \mathrm{C}$, in Pigures 3 and 5 . It has been known for a long time that at about $350^{\circ} \mathrm{C}$, the principal form of deformation predominating in uranium shifts from twinning, which has been more active below this temperature, to $\operatorname{silp}(9,12,17)$. McLean $(20$, p. 88) brings out the point that the stress for twinning tends to be large at room temperature and below, with the result that twinning occurs under conditions where yield stress is high. For example, he states that twinning will be particulariy large at 10\% temperatures or high rates of strain in bec metals. Uranium has orthorhombic symmetry and it can be considered as having a deformed hexagonal close-packed structure $(21,22)$, so it is certainly not bec. However, one can not help notice that in Pigure 3 and in Pigure 5 also, the deviation from the smooth plot seemed to occur for the low rate of loading before it did for the others. Thus, twinning appears to give precedence to slip sooner at the low rate of 
loading. The other two rates of loading are closer together and so one is unable to state definitely that twinning will tend to predominate longer at the higher rate of loading. The plot of reduction in area would substantiate such a statement however. So it is postulated that there is not only a temperature dependence on when slip plays the paramount role as a mechanism of deformation in uranium but also a-rate of loading dependence.

One must remember however, as Nichols (16) and others have brought out, that not too much reliance should be put in graphs of percentage elongation or percentage reduction in area. Nichols stated that values he had seen reported for percentage elongation in uranium had ranged at room temperature from $5-15 \%$ and at $500^{\circ} \mathrm{C}$, from $5-57 \%$. Perhaps a good example of this would be to take Figures 4 and 6 and to try to state wat the influence of rate of strain is in these plots. One could not say that there is definitely an increase or decrease in either percentage elongation or reduced area with increased rate of loading though the low rate of loading seems to present the lowest value for both, in the majority of cases.

The slope, $\frac{\Delta \ln \sigma}{\Delta \ln \epsilon}=1 / m$ of the stress-strain curve noticeably decreases as the temperature increases (Pigure 7). The refore, $w$ in the formula $G \times A \sigma^{m}$, for plastic flow, increases considerably with increasing temperature. This result 
indicates that a much smaller stress is needed to cause a certain strain in uranium at a high temperature than is needed at a low temperature. The implication is that the amount or magnitude of strain hardening which uranium will undergo at a given strain rate becomes less as the temperature is increased.

Some significance may also be attributed to the fact that the region of validity of the formula, $E=A$ ol not only commences sooner but also becomes smaller and smaller as temperature increases (Figures 13, 14 and 15).

In considering a certain temperature, the variation of $\frac{\Delta \ln \sigma}{\Delta \ln \epsilon}$ as a function of strain rate (Figure 8) indicates that the degree of strain hardening is least for the lowest rate of loading. The influence of strain rate is nowhere near as great as the influence of temperature but it is still noticeable, With a low rate of loading, the material appears to have the opportunity to rearrange itself in some manner 80 that strain hardening does not occur to as great an extent as it does in the faster rates of loading.

As was mentioned in the previous section of this report, the modulus of elasticity and yield strength of uranium are difficult to determine. Nichols (16) found that the modulus of elasticity reportedly varied at room temperature from $15.8-30.0 \times 10^{6}$ psi. Nichols adds further that the proportional limit is even less well defined as the temperature increases and so problems become even greater. This is men- 
tioned merely to precaution the reader on the use of the values of the elastic modulus. However, for both the properties of modulus of elasticity and yield strength, the curves agree quite nicely with reference values $(17,23)$. As functions of temperature, both properties decrease with increasing temperature and display the familiar variation from the smooth curve in the range of $350^{\circ} \mathrm{C}$. The yield stress plot of Pigure 11 illustrates the digression well but deviations from smooth plots in Pigure 9 for the modulus of elasticity are guite apparent in this range also.

For the low rate of loading, several values of the modulus of elasticity are missing. The reason is, as a result of the shape of the stress-strain curve, an uncertainty exists in deciding what portion of the curve to use in order to calculate the modulus for the low strain rate. Therefore, where the curve bad no initial linear region, no elastic modulus was determined. Actually one wonders whe ther these values are valid an yway since the low rate tensile test is almost a creep test. Bernett (1) stated that for the material he worked with, the lower values obtained at a very low strain rate are thought to be result of the distortion of the stress-strain curve due to creep. Thus, he felt that these values really should not be utilized since the initial portion of the stress-strain curve does not seem to be elastic under conditions of very low strain rate and high temperature. How- 
ever, the values for the modulus of elasticity are reported and one can observe the influence of the rate of loading on them in Figure 9. The modulus certainly increases with bigher strain rates.

The influence of the rate of loading on the yield stress (Figure 12) can be taken as an indication of strain hardening. If the yield stress increases, this is taken to be a strong indication that the amount of strain hardening has increased. From figure 12, one can see that even though the influence is sma11; there does appear to be an increase in yield stress with increasing strain rate, especially at the higher temperan tures. Thus, once again it can be surmised that the degree of strain hardening in normal alpha uranim increases with an increase in the rate of loading.

Lubahn (9) in his dexivation of a general flow equation in the region of plastic flow utilizes a basic equation for metals, as was cited in the Iiterature review. $\epsilon=A$ ol $\left.\right|_{\epsilon, T}$ This formula applies to uranium in the regions as marked in the stress-strain curves of Pigures 13, 14. and 15." One of the main reasons for including these $\log$ plots vas to indicate how the portion of the curve, which equation 1 holds for, varies with temperature. As was previously mentioned, the left hand limit and also the extent of the region of validity both vary with temperature. The right hand limit of the region considered in the three figures was defined because of necking 
down occurring in the specimen. The $x-y$ recorder was not able to correct for this and thus the stress values decreased correspondingly resulting in incorrect data beyond this limit.

Equation 2 is found to be valid as a result of plots in Figure 16. There is one basic difficulty however in utilizing this equation and that has to do with the Iimited portion of the curve where such an equation will hold. It is valid ouly for plastic flow as was equation 1 and thus realiy should not be considered too near to the beginning of the test. Therefore, in order to be able to correlate this equation to equation 1 and still be in a valid region, a strain within the limits of the curve where equation 1 was valid has been taken. Thus, different strain values were used to ascertain the stress as the temperature increased. So even though equation 2 seems valid from the linear plot results of Pigure 16, one could not correlate this equation along with equation 1 into one general flow equation since the regions of validity of the two equations vary with temperature. A general flow equation such as equation 4 is therefore impossible. A less general equation with specific validity regions for different temperatures however would be possible.

Holden (12, P. 66) Indicates that it is very difficult to assess the value of tabulated data unless the original stress-strain curves are included. Thus, Pigures 17, 18 and 19 are valuable in the sense that they show the results of 
the tensile tests performed. One should readily note from the se curves that for temperatures higher than $400^{\circ} \mathrm{C}$ the curves are spread wuch further apart than they are below this temperature. The predominance of the slippage deformation mechanism in this range for uranium may be the cause of that.

One can see directiy from the stress-strain curves (Pigures 20, 21 and 22), how the rate of loading influences the tensile properties of uranium. Por the three different strain rates in Figures 20 and 21 , the curve corresponding to the low rate of loading is predominantig on the lower side of the three and the other two respectively higher as their strain rates increase. However, all three curves in these two plots are quite close together. Figure 22 brings out the role that temperature plays since its values are taken at $550^{\circ} \mathrm{C}$ and Figures 20 and 21 are plots at $150^{\circ} \mathrm{C}$ and $350^{\circ} \mathrm{C}$. So, the rate of loading influence on normal alpha uranium is greater at the higher temperatures than at room temperature. of course, creep will play more of a major role as the temperature reaches higher 1imits also. 


\section{SUMMARY AND CONCLUSIONS}

The investigation consisted of performing 40 tensile tests on normal alpha uranium in order to determine the influence of the rate of loading on the tensile properties of alpha uranium.

The tests were conducted in the temperature range from $25^{\circ} \mathrm{C}$ to $6000^{\circ} \mathrm{C}$ at three constant loading rates $\left(0.0017 \mathrm{~min} .^{-1}\right.$. $0.0130 \mathrm{~min}^{-1}$ and $0.0400 \mathrm{~min}^{-1}$ ).

The conclusions made from a study of the results are 1. The tensile properties of uranium are influenced by the rate of loading, however the effect of a rate change is much 1ess, in magnitude, than the effect caused by a change in temperature.

2. The tensile strength, yield strength and modulus of elasticity are the properties of uranium most affected by the rate of loading, especially at the higher temperatures. A general statement can not be made about the Infiuence of rate of loading on the percentage elongation (in 1.5 inch gage length) and the percentage reduction in area for uranium but the lowest strain rate seems to give the lowest values for both of these properties in the majority of cases.

3. The slope of the uranium stress-strain curve in the region of plastic flow is affected by the rate of loading and in general, the smallest slope is observed for the lowest 
rate of loading.

4. The lowest rate of loading appears to cause the smallest amount of strain hardening in uranium at a specific temperature.

5. The predominance of the twinning and s1ip mechanisms of deformation in uranium may not only be affected by temperature but also by rate of loading. 


\section{SUGGESTED TOPICS FOR FURTHER INVBSTIGATION}

A more complete analysis to observe the effect of rate of loading on twinning and slip mechanisms in uranium might turn out to be very interesting. This same analysis might be carried out on other materials which display a change in the predominant mode of deformation from twinning to slip at a definite temperature. Thus, one might be able to generalize about such an effect.

A second field of inquiry might have to do with a consideration of the region of validity of the equation $\epsilon=A$ om as seen in Figures 13, 14 and 15 of this thesis. One could look into the reason behind the variation with temperature in the limits of validity as well as changes in the size of the limiting region for temperature changes. Thermal expansion of uranium, which simply causes a separation of the atoms in the array, may have a great deal of significance in connection with this.

Since a change of strain rate was found to influence only slightly the slope of the stress-strain curve in the plastic region compared to the effect of temperature, equations for prediction of stresses in flexural creep might be able to utilize such a slope. This could prove to be an interesting source of analysis also. 


\section{LITERATURB CITBD}

1. Bernett, E. C. Short time, elevated temperature, stressstrain behavior of tensile, compressive, and column members. U. S. Atomic Energy Commission Report WADCTR-59-484 [Wright Air Development Center, WrightPatterson AFB, Ohiol; 1959.

2. Moon, D. P. and J. B. Campbe11. Bffects of moderately high strain rates on the tensile properties of metals. U. S. Atomic Energy Commission Report DMIC-Memo-142 [Battelle Memorial Inst. Defense Metals Information Center, Columbus, Ohio]. 1961.

3. Steide1, R. F., Jr. and C. E. Makerov. The tensile properties of some engineering materials at moderate rates of strain. American Society for Testing and Materials Bulletin 247:57-64. 1960.

4. Davis, E. A. The effect of speed of stretching and the rate of loading on the yielding of mild steel. American Society of Mechanical Engineers Transactions $60: A-137$ - A-140. 1938 .

5. Morrison, J: L. The influence of rate of strain in tension tests. Bngineer 158:183-185. 1934.

6. Jones, P. G. and H. P. Moore. An investigation of the effect of rate of strain on the results of tension tests of metals. American Society for Testing and Materials Proceedings 40:610-624. 1940.

7. Pry, L. H. Speed in tension testing and its influence on yield point values. American Society for resting and Materials Proceedings 40:625-642. 1940.

8. Austin, A. L. and R. P. Steldel, Jr. The tensile properties of some engineering materials at high rates of strain. U. S. Atomic Bnergy Commission Report UCRL 5343 [California. Univ., Iivermore. Radiation Lab.]

9. Lubahn, J. D. Derivation of stress, strain, temperature, strain rate relation for plastic deformation. American Society of Mechanical Bngineers Ironsactlons $698229-230.2947$. 
10. Hueschen, R. E. Mechanical and physical properties of uranium. U. S. Atomic Energy Commission Report Hin-34868 C 8 [Hanford Atomic Products Operation. Richland, Wash.]. 1955.

11. Kaufmann, A. R. Nuclear reactor fuel elements; metallurgy and fabrication. New York, N. Y., Interscience Publishers. 1962.

12. Holden, A. N. Physical metallurgy or uranium. Reading, Mass., Addison-Wesley Publishing Co., Inc. 1958.

13. American Society for Testing and Materials, Selected A. S. T. M. Standards for Students in Bngineering. Philadelphia, Pa., Author. 1950.

14. Lewis, $R$. $W$. The tensile properties of metals in the inelastic range of stress. USAEC Rept. ISC-527 (1954).

15. Bohn, J. R. and Glenn Murphy. A high-temperature vacuum extensometer. U. S. A tomic Bnergy Commission Report IS-167 [Iowa State University of Science and Technology, Ames. Inst. for Atomic Research]. 1960.

16. Nichols, R. W. Uranium and its alloys. Nuclear Engineering 2, No. 18:355-364. September. 1957.

17. Pedersen, K, and Glenn Murphy. Bffects of temperature on the mechanical properties of normal uranium dingot. U. S. Atomic Bnergy Commission Report IS -400 [Iowa State University of Science and Technology, Ames. Inst. for Atomic Research]. 1962.

18. Hue schen, R. W. and C. H. Pitt. Initial investigation of the mechanical properties of uranium at elevated temperatures. U. S. Atomic Energy Comission Report IFW-26426 (Hanford Works, Richland, Wash.). 1952.

19. Bernard, J. et G. Courepu. Comportement mécanique de 1'uranium. Centre D'btudes Nucléaires De Saclay Rapport Commissariat A I'Energie Atomique No.693. 1957.

20. McLean, D. Mechanical propertice of metals. New York, N. Y., John Wiley and Sons, Inc. 1962. 
21. Jacob, C. W. and B. B. Warren. Crystalline structure of uranium. American Chemical Society Journal 598 2588-2591. 1957.

22. Lucker, C. W., Jr: The crystal structures of metaliic uranium. American Society for Metals Transactions 428 762-770. 1950 .

23. Hunter, D. and Glenn Murphy. Thermal stress analysis of a cylinder of semi-piastic material. U. S. Atomic. Energy Commission Report ISC-839 【Iowa State College. Ames . 1956 . 
APPENDIX 


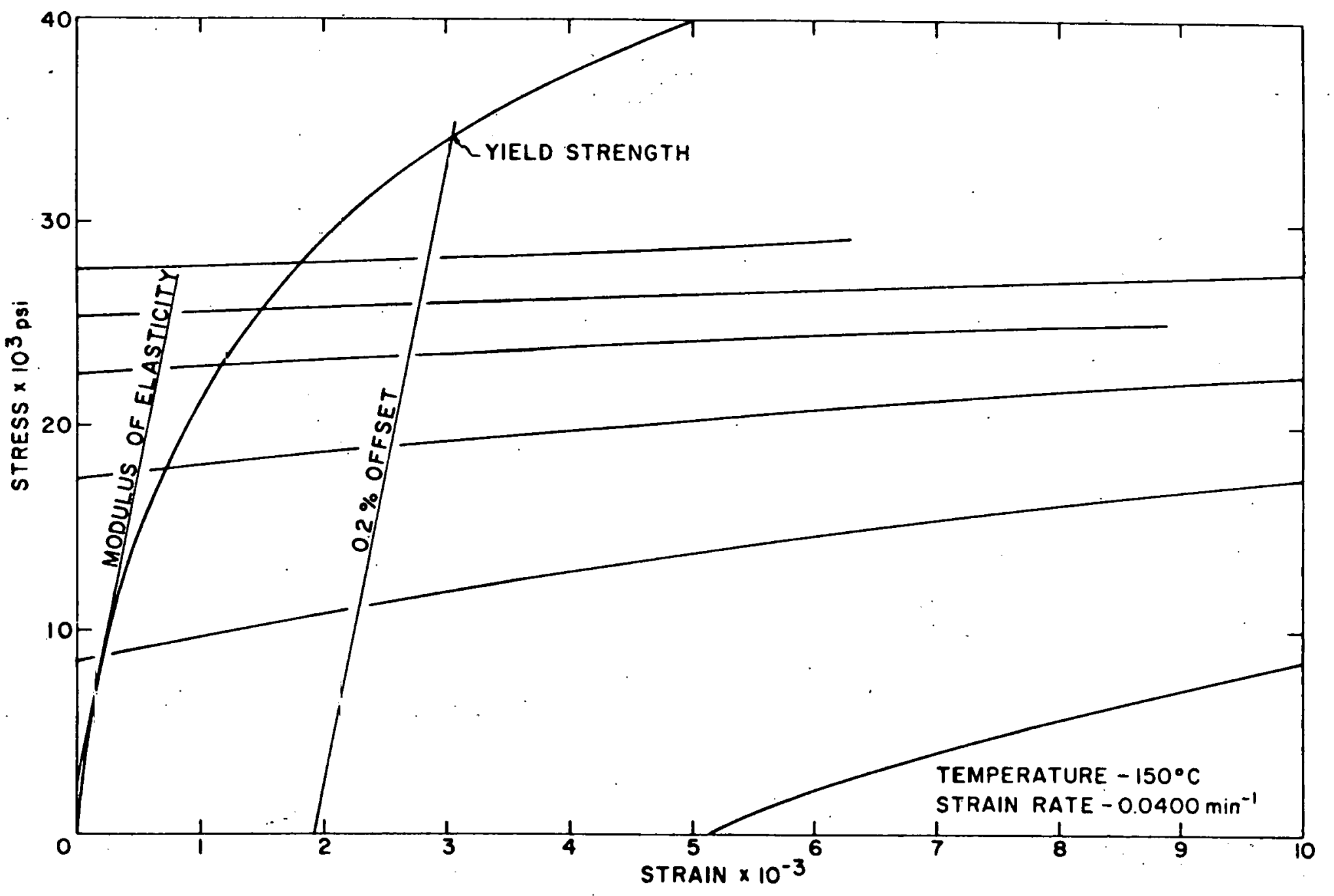

$\approx$

Figure 23. Original stress-strain curve for highest rate of $10 a d i n g$ at $150^{\circ} \mathrm{C}$ 


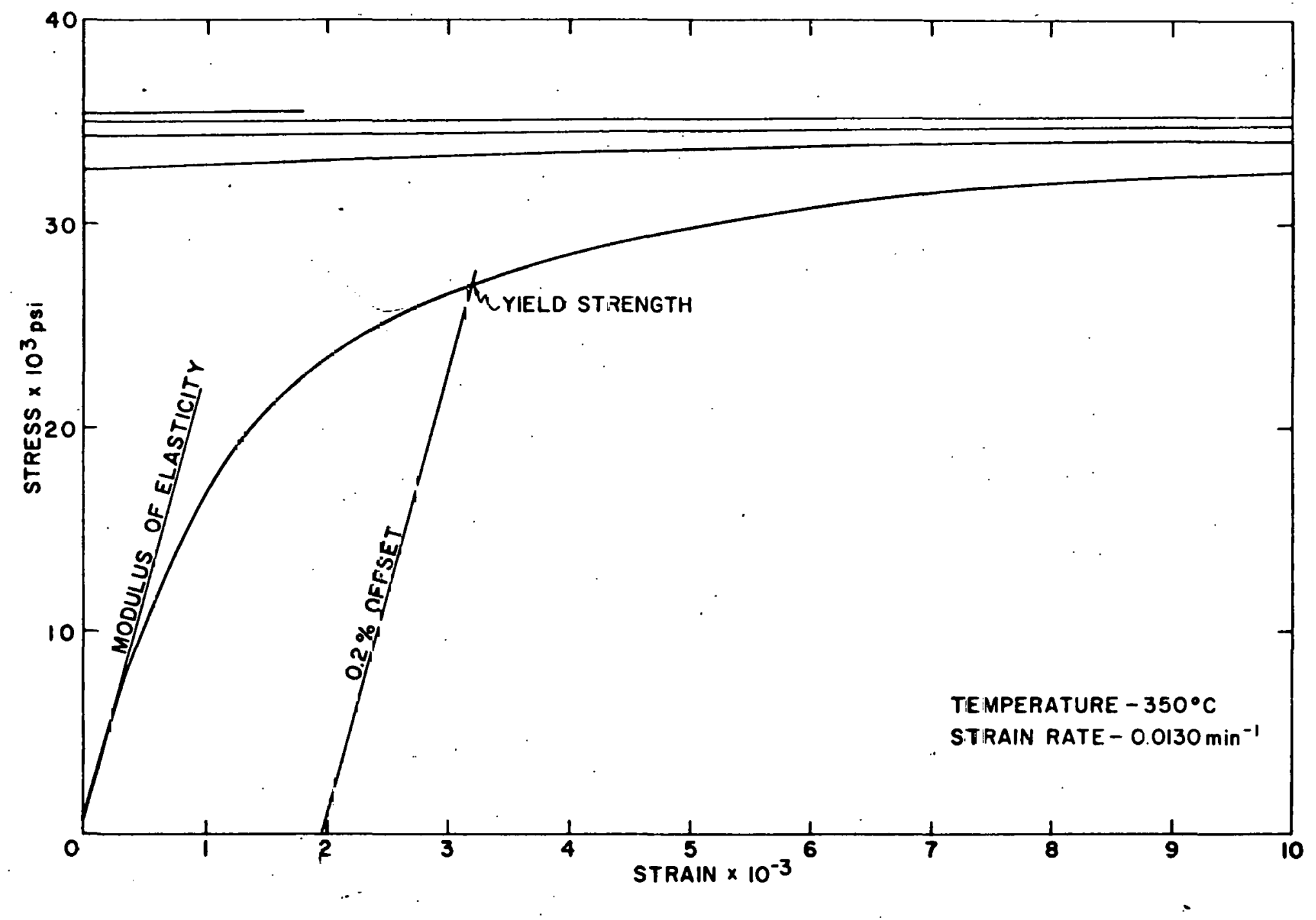

$\stackrel{\sim}{\sim}$

Pigure 24: Original stress-strain curve for medium rate of loading at $350^{\circ} \mathrm{C}$ 


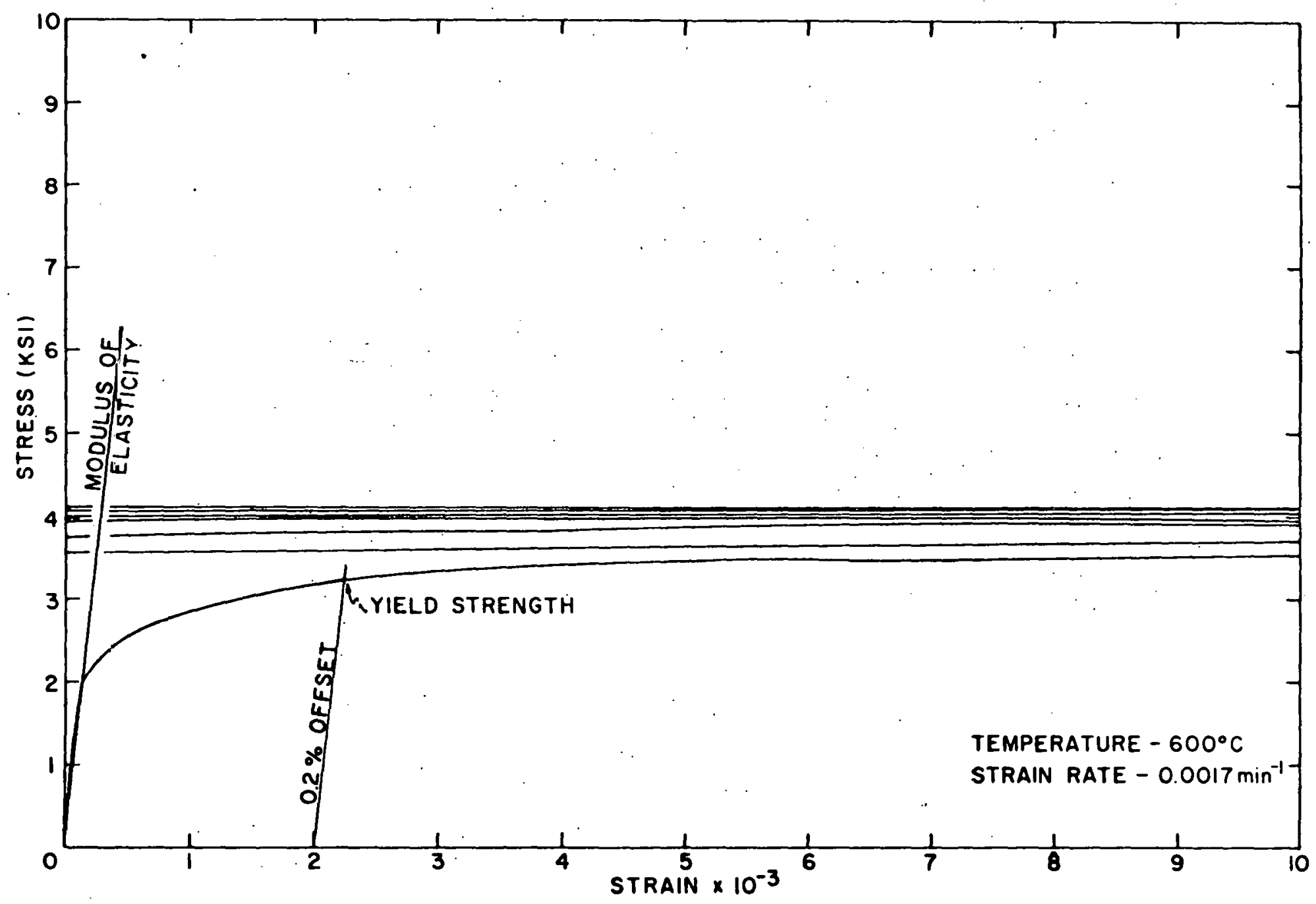

Pigure 25. Original stress-strain curve for lowest rate of loading at $600^{\circ} \mathrm{C}$ 